IZA DP No. 8634

Health Status and the Allocation of Time:

Cross-Country Evidence from Europe

J. Ignacio Gimenez-Nadal

Jose Alberto Molina

November 2014

Forschungsinstitut

zur Zukunft der Arbeit

Institute for the Study

of Labor 


\title{
Health Status and the Allocation of Time: Cross-Country Evidence from Europe
}

\author{
J. Ignacio Gimenez-Nadal \\ University of Zaragoza \\ and CTUR
}

\section{Jose Alberto Molina}

University of Zaragoza

and IZA

\section{Discussion Paper No. 8634 \\ November 2014}

\author{
IZA \\ P.O. Box 7240 \\ 53072 Bonn \\ Germany \\ Phone: +49-228-3894-0 \\ Fax: +49-228-3894-180 \\ E-mail: iza@iza.org
}

Any opinions expressed here are those of the author(s) and not those of IZA. Research published in this series may include views on policy, but the institute itself takes no institutional policy positions. The IZA research network is committed to the IZA Guiding Principles of Research Integrity.

The Institute for the Study of Labor (IZA) in Bonn is a local and virtual international research center and a place of communication between science, politics and business. IZA is an independent nonprofit organization supported by Deutsche Post Foundation. The center is associated with the University of Bonn and offers a stimulating research environment through its international network, workshops and conferences, data service, project support, research visits and doctoral program. IZA engages in (i) original and internationally competitive research in all fields of labor economics, (ii) development of policy concepts, and (iii) dissemination of research results and concepts to the interested public.

IZA Discussion Papers often represent preliminary work and are circulated to encourage discussion. Citation of such a paper should account for its provisional character. A revised version may be available directly from the author. 
IZA Discussion Paper No. 8634

November 2014

\section{ABSTRACT \\ Health Status and the Allocation of Time: Cross-Country Evidence from Europe}

This paper analyzes the relationship between reported health status and time allocation decisions in six European countries. Using the Multinational Time Use Study, we find that a better perception of own health is associated with less time devoted to sleep, personal care, and non-market work, for both men and women, and with less time in leisure for men, while it is associated with more time in market work for both men and women. We also find that the relationship with activities is very similar across countries, and that market work has a relationship of substitution with sleep, personal care, non-market work, and leisure, with mixed evidence for the rest of the uses of time. These findings are consistent with prior results regarding health, market work, and leisure in the US. However, in contrast to the large positive correlation between health and home production in the US, we find a large negative correlation between these activities in the six European countries analyzed. This study represents a first step in understanding cross-country differences in the relationship between health status and time devoted to a range of activities, in contrast with other analyses that have mainly focused only on market work. A better understanding of these cross-country differences may help to identify the effects of public policies on individual uses of time.

JEL Classification: D13, J16, J22

Keywords: health, time allocation, Multinational Time Use Study

Corresponding author:

Ignacio Gimenez Nadal

Department of Economic Analysis

Faculty of Economics

University of Zaragoza

C/ Gran Via 2, 3rd floor

50005 - Zaragoza

Spain

E-mail: ngimenez@unizar.es

\footnotetext{
* This paper was partially written while Jose Alberto Molina was Visiting Fellow at the Department of Economics of Boston College (US), to which he would like to express his thanks for the hospitality and facilities provided. This paper has benefited from funding from the Spanish Ministry of Economics (Project ECO2012-34828).
} 


\section{INTRODUCTION}

In this paper, we analyze the relationship between self-reported health status and the time devoted to different activities for six European countries. A number of papers have studied health from the perspective of labour economics, with many of them focusing on the relationship between health status and the labour market outcomes of older workers (Currie and Madrian; 1999; Au et al., 2005; Disney et al., 2006; Barnay, 2010; Jones et al., 2010). However, little is known about the relationship between health and other uses of time, such as home production or leisure. It could be that better health is associated with greater productivity in home production, leading to a substitution effect that increases the time devoted to this activity, despite the income effect associated with more time spent at work (i.e., higher income may lead to more outsourcing of domestic goods). The understanding of the relationship between health and time allocation decisions is important, as time is scarce and a crucial factor in well-being (Kahneman et al., 2004; Kahneman and Krueger, 2006; Krueger, 2007; Stiglitz et al., 2009).

According to Grossman's seminal work on the concept of health capital and the demand for health (Grossman, 1972a, 1972b), health can be considered as a durable stock capital of individuals, and thus a component of the stock of individual human capital. Investments in health, by reducing morbidity and prolonging life, increase the amount of time available to produce money earnings and commodities in the future. But time is also required to produce/maintain health and to obtain medical care. For instance, the evidence shows that regular physical activity is associated with decreased risk of obesity, chronic disease, premature mortality, and reduced healthcare utilization (USDHHS 1996; Sari 2009). Other research has focused on the role of time allocation decisions in the production of health, both theoretically and empirically (Cutler et al., 2003; Philipson and Possner, 2008; Mullahy and Robert, 2010).

Focusing on the effect of health on the uses of time, Podor and Halliday (2012) develop a model based on Gronau (1980), in which health affects time allocation decisions via productivity in activities. These authors consider that the individual derives utility from a market good, a home-produced good, and leisure, and they assume that individuals are endowed with a stock of health that affects their productivity in both market and non-market goods (the production of health is not considered in this model). Under the assumption that market and home-produced goods are perfectly substitutable, they find that, even if the non-market effects of health status dominate their market 
effects, so that healthier people work more at home, it is still possible to observe that healthier people also work more in the market. This model is compatible with better health positively related to market work, and to less time in non-market work.

To the best of our knowledge, only two studies have directly analyzed the relationship between health and time allocation decisions other than market work time. Podor and Halliday (2012) analyze the relationship between health and time allocation in the US, and find that better health is associated with large positive effects on home production, and large positive effects on market production, but less consumption of leisure. Gimenez-Nadal and Ortega (2013) analyze the relationship between health status and the time devoted to both market and non-market work in Spain, and find that better health is associated with an increase in the hours of market work and a decrease in the time devoted to non-market work. Thus, evidence on the relationship between health and individual time allocation decisions is scarce, and more research on this issue is needed.

We contribute to the literature by analyzing the relationship between the selfreported health status of individuals and the time devoted to sleep, personal care, market work, non-market work, and leisure, in six European countries. An important concern in the literature is that health may be endogenous to time allocation decisions (e.g., in the labour supply literature, we find Stern (1989), Kreider (1999), Dwyer and Mitchell (1999). Benitez-Silva et al. (2004), and Cai and Kalb (2006), among others) and hence self-reported health may introduce a source of endogeneity that can affect the estimated relationship between health and time allocation decisions (Kerkhofs and Lindeboom, 1995; Crossley and Kennedy, 2002; Lindeboom and Van Doorslaer, 2004; Lindeboom and Kerkhofs, 2009). We agree with Podor and Halliday (2012) that there are difficulties in finding a good instrument for health in a dataset like ours. Accordingly, we acknowledge that the approach here is largely descriptive, and we limit our discussion to relationships between health and time allocation decisions, rather than causations.

We examine diary data for the following European countries: France (1998), Germany (2001), Italy (2002), the Netherlands (2000 and 2005), Spain (2000), and the United Kingdom (2000 and 2005). We offer descriptive evidence on the relationship between health and the time devoted to the different activities, together with estimated partial correlations, while controlling for age and its square, education, the number of 
children under 18 in the household, the age of the youngest child, the household size, and civil status. In doing so, we also allow for correlations in the unobserved determinants of the activities by allowing the error terms in regressions to be jointly normally distributed, with no restrictions on the correlation (Seemingly Unrelated Regression, SURE). We find that, in general, a better perception of own health is associated with less time devoted to sleep, personal care, and non-market work, and with less time in leisure for men, while it is associated with more time in market work for both men and women. We also find that the relationship with activities is very similar across countries, and that market work has a relationship of substitution with sleep, personal care, non-market work, and leisure, with mixed evidence for the rest of the relationships.

When we control for other factors for men we find that, in all countries, better health is associated with decreases in the time devoted to sleep, personal care, non-market work, and leisure, while they are associated with increases in the time devoted to market work. These results are consistent with the results obtained by Podor and Halliday (2012) for market work and leisure in the US, but not for non-market work. For women we observe that, in all countries, better health is associated with decreases in the time devoted to sleep, personal care, and non-market work, while they are associated with increases in the time devoted to market work. These results are consistent with the results obtained by Podor and Halliday (2012) for the US regarding market work, but not for non-market work and leisure. Exceptions to these patterns are found for women in Italy, where personal care and better health are positively related, and better health has a non-statistically significant association with the time devoted to market work. In the case of leisure, the results for the relationship between health status and the time devoted to this activity are mixed, and while in Italy we find a positive association, we find a negative association in the United Kingdom, with no statistically significant associations for the remaining countries.

Considering the relationships between the activities (i.e., correlations), for men we obtain negative correlations between market work and the rest of the activities, especially for non-market work and leisure, and smaller correlations are found between market work, and sleep and personal care. For the remaining relationships, we find mixed evidence. In the case of women, we obtain negative correlations between market work and the other activities, especially for non-market work and leisure. Smaller 
negative correlations are found between market work, and sleep and personal care. Nonmarket work appears to be positively correlated with personal care, and negatively correlated with leisure.

In studying several countries, our work crucially adds to the study of the relationship between health status and time allocation decisions, including the most recent work by Podor and Halliday (2012) and Gimenez-Nadal and Ortega (2013). Specifically, we are able to improve our understanding of how better self-reported health status relates to market and non-market work activities, leisure, and personal care, and we compare our results for a broad group of industrialized economies with prior results for the US (Podor and Halliday, 2012). In contrast to the reported relationship between health and time allocation decisions in the US, where better health is associated with large positive effects on home production and market production, but less consumption of leisure, we fail to find such relationships for home production and leisure in our six countries, indicating that the relationship between health and time allocation decisions is unique to the US. Our paper also expands recent cross-country studies such as Burda et al. (2008), Gershuny (2009), Hook (2006), Gauthier et al. (2004), and Gimenez-Nadal and Sevilla (2012) among others, studies that generally analyze the uses of time for a variety of developed economies, but do not consider the correlation structure among the different activities. Our paper extends these cross-country comparisons by documenting for the first time the relationships between the different uses of time.

The paper is organized as follows. Section 2 describes the data and the variables, and Section 3 presents the empirical evidence. Section 4 describes our empirical strategy. Section 5 presents the main results, and Section 6 sets out our main conclusions.

\section{DATA AND VARIABLES}

For the analysis of the relationship between health status and time allocation decisions, we use the Multinational Time Use Survey (MTUS), ${ }^{1}$ an ex-post harmonized crosstime, cross-national, comparative time use database, coordinated by the Centre for Time Use Research at the University of Oxford. It is constructed from national randomly-

\footnotetext{
1 Information on the variables, and on how to access the data, is available on the MTUS website: http://www.timeuse.org/mtus. See Fisher et al. (2011) for a full description of the MTUS documentation. We use version W53 (accessed in October 2010) of the MTUS.
} 
sampled time-diary studies, with a common series of background variables, and total time spent in 41 activities (Gershuny, 2009). The MTUS provides us with information on individual time use, based on diary questionnaires in which individuals report their activities throughout the 24 hours of the day. The MTUS includes 41 activities, defined as the 'primary' or 'main' activity individuals were doing at the time of the interview. Thus, we are able to add up the time devoted to any activity of reference (e.g., paid work, leisure, TV watching) as ‘primary’ activity.

It is important to acknowledge that, in this paper, the fact that most of our analysis is based on a comparison of broad classifications of activities (sleep, personal care, market work, non-market work, and leisure) provides a good basis for meaningful comparisons across countries. As Gimenez-Nadal and Sevilla (2012) point out, the harmonization exercise by the CTUR team addresses differences in survey methodologies, such as different response rates (especially the lower response rate of some of the surveys), whether they covered, or not, the twelve months of the year, the sampling frame, and differences in activity codes. Complete information on the methods applied by the MTUS team can be found in http://www.timeuse.org/sites/ctur/files/858/mtus-userguide-r6-july-2013.pdf

The advantage of time-use surveys over stylized questions, such as those included in the data bases ECHP, BHPS, and SOEP (where respondents are asked how much time they have spent, for example, in the previous week, or normally spend each week, on market work or housework) is that diary-based estimates of time use are more reliable and accurate than estimates derived from direct questions (Juster and Stafford, 1985; Robinson and Godbey, 1997; Bianchi et al., 2000; Bonke, 2005; Yee-Kan, 2008). In the labour supply literature, Klevmarken (2005) argues that information on actual hours of work from time-use surveys is more relevant than normal hours or contracted hours generally reported in stylized questions. This author shows that time-use data yields much smaller estimates of wage-rate effects, compared to measures of normal hours of work, which may have important implications for tax policy design, among other things. Thus, in the same way that money-expenditure diaries have become the gold standard in the consumption literature, so have time-use diaries become the preferred method of gathering information about time spent on market work, non-market work, and leisure. Most studies documenting how individuals use their time are now based on these data 
sets, including recent studies of the analysis of trends in time use (Aguiar and Hurst, 2007; Guryan et al., 2008; Gimenez-Nadal and Sevilla, 2012; Sevilla et al., 2012). ${ }^{2}$

For the sake of comparison with existing studies (e.g., Aguiar and Hurst 2007), and to minimize the role of time allocation decisions that have a strong inter-temporal component over the life cycle, such as education and retirement, we restrict the sample used throughout our analysis to non-retired/non-student individuals between the ages of 21 and 65 (inclusive), so results should be interpreted as being 'per working-age adult'.

For the selection of countries, we select countries with information about individual health. To measure the health of individuals, we use the question about self-reported health status included in the survey, where respondents typically answer the question 'how is your health in general?' with five possible responses: “very poor health” (1), “poor health” (2), “fair health” (3), “good health” (4) and “very good health” (5). The CTUR team has recoded the categories to include the following values: "very poor/poor health” (1), “fair health” (2), “good health” (3) and “very good health” (4). The availability of information on health in the surveys leaves us with the following countries: France (1998), Germany (2001-02), Italy (2002-03), the Netherlands (2000 and 2005), Spain (2002-03) and the United Kingdom (2000 and 2005). The information gathered by this question is known as the "Self-Assessed Health Status" (SAHS) measure. $^{3}$

Although self-assessed health status (SAHS) measures are increasingly common in empirical research (Deaton and Paxson, 1998; Ettner, 1996; Podor and Halliday, 2012, Gimenez-Nadal and Ortega, 2013), prior literature has identified a number of reasons why self-reported measures of health status may cause biases (e.g., Bound, 1991). ${ }^{4}$ An individual may face incentives, both economic and psychological, that may affect the response to the question, resulting from the possibility that the unemployed may report

\footnotetext{
2 The MTUS has been widely used across the social sciences (Gershuny, 2000; Gershuny and Sullivan, 2003; Gauthier et al., 2004; Guryan, Hurst and Kearney, 2008; Gershuny, 2009, Gimenez-Nadal and Sevilla, 2011;2012; Gimenez-Nadal and Molina, 2013).

${ }^{3}$ Table 1 in Appendix shows the technical information of the surveys included in the study.

${ }^{4}$ The analysis of the effect of health on time allocation decisions using these subjective measures may be incorrectly estimated if individuals use health as a justification for leaving the labor force early. This phenomenon has been referred to as the "justification hypothesis". When subjective health assessments measure leisure preferences rather than "true health capacity", estimates of health effects will tend to be biased in the direction of poorer reported health driving retirement. Those who enjoy their work will downplay their health problems and work longer, while those who dislike their work may exaggerate health problems and retire sooner. Several studies on this "justification" hypothesis have confirmed the endogeneity of self-reported health measures (Chirikos and Nestel, 1984; Anderson and Burkhauser, 1985; Bazzoli, 1985; Bound, 1991; Haveman et al. 1994).
} 
poor health to justify their non-participation (the 'justification hypothesis' known in the literature, see Anderson and Burkhauser, 1985; Stern, 1989; Bound, 1991; Dwyer and Mitchell, 1999; Kreider, 1999). In a recent study, Gimenez-Nadal and Ortega (2013) analyze the relationship between health status and the time devoted to market work and household production, and find that reverse causality can bias the coefficients measuring this relationship. We acknowledge this, and the approach we adopt here is descriptive, similar to Podor and Halliday (2012).

The idea of placing different uses of time in different categories requires some care in defining terms. The so-called third person criterion, for example, excludes from the definition of leisure any activity that can be carried out by some third party without losing the intended utility for the individual. Unfortunately, this involves questionable assumptions, such as that the enjoyment derived from work can legitimately be ignored, and that all leisure is, by definition, enjoyable. However, one quarter of the time that would be considered leisure according to the conventional implementation of the third person criterion, and one third of what would conventionally be considered work, is unexpectedly placed by diarists (Gershuny, 2013). Certain activities, such as sleeping, eating, personal and medical care, or resting, do not fall comfortably into a means vs. ends classification. Such activities cannot be purchased in the market, but they may not be considered leisure in the sense that they are necessary for life.

Nonetheless, some variation in the time spent in these activities may result from conscious choice. Biddle and Hamermesh (1990) show that sleep time responds to economic incentives such as wages, while Hamermesh (2002) and Hallberg (2003) show that couples tend to synchronize their leisure activities. The decreasing marginal utility of sleep (and of other consumption activities) is indeed shown by Gershuny (2013) using (subsequent) diary reports of enjoyment. Similarly, many of the tasks constituting child care can be purchased in the market, so it could be conceptualized as a part of unpaid production (Aguiar and Hurst, 2007; Fisher et al., 2007; Guryan, Hurst and Kearney, 2008). However, parents report that time spent with their children is among their more enjoyable activities, especially when compared to other standard home production activities (Juster and Stafford, 1985; Robinson and Godbey, 1997; Kahneman et al., 2004; Kahneman and Krueger, 2006; Krueger, 2007; Guryan, Hurst and Kearney, 2008). 
Rather than trying to resolve this debate on theoretical grounds, we adopt an empirical approach, and follow Burda et al. (2008) in our definitions of time use categories: sleep, personal care, market work, non-market work, and leisure. Personal care refers to things that individuals cannot pay others to do, but must do for themselves, at least to some extent, for example, eating, an activity that is necessary for survival. Market work refers to those activities in which people would not be working the marginal hour if they were not paid, so that at the margin market work is not enjoyable (or at least is less enjoyable than any non-work activity at the margin). Nonmarket work refers to activities individuals engage in at home, using their own time and some purchased goods, and have the common characteristic that they could pay another to perform them, while not themselves being paid. Finally, Leisure includes all activities that individuals cannot pay others to do, and that do not really have to be done at all. (Table A2 in the Appendix shows how the activities of the MTUS have been included in the various time use categories.

We do the analysis by gender for two reasons. ${ }^{5}$ First, the prior time use literature has shown that time use patterns of men and women differ and the same factors affect men and women differently (Gershuny, 2000; Gauthier et al., 2004; Kalenkoski et al., 2005; Aguiar and Hurst, 2007; Connelly and Kimmel, 2009; Gimenez-Nadal and Sevilla, 2012; Gimenez-Nadal and Molina, 2013). Second, Schneider et al. (2012) find that the responses to health perception questions vary between male and female respondents, pointing to gender-specific perceptions and assessments of health. Additionally, Jürges (2007) and Bago d’Uva et al. (2008) have shown that the assessments of health categories differ between countries, implying that we should carry out our analysis by country.

\section{EMPIRICAL EVIDENCE}

Figures 1-A and 1-B show, for each country, the overall time devoted to the five time use activities, according to the health status of men and women, respectively. We

\footnotetext{
${ }^{5}$ We have estimated econometric models by country, where we pool the samples of males and females, and include a gender dummy to see if there are differences in the time devoted to different activities by males and females. We find that males devote less time to sleep, personal care, and housework, and more time to market work. These findings are consistent with existing research (Gershuny, 2000: Gimenez-Nadal and Sevilla, 2012). In the case of leisure, males devote more time to this activity in France, Italy, Spain, and the United Kingdom, less time to this activity in the Netherlands, and we find no gender differences in the time devoted to leisure in Germany. Results are available upon request.
} 
average, for each country and health status, the time devoted to these activities. ${ }^{6}$ For instance, for the United Kingdom, we average the time devoted to sleep, personal care, market work, non-market work, and leisure, by men and women reporting "poor health”, “fair health”, “good health” and "very good health”. For the computation of average values, we use the demographic weights included in the survey. ${ }^{7}$ We observe that, for all the countries, there are negative relationships between health status and the time devoted to sleep, personal care, non-market work and leisure, as the overall time devoted to these activities decreases as self-reported health status improves. We find a positive relationship between health status and the time devoted to market work. Thus, better self-reported health is associated with more market work, and less time in other activities. We also find that there are cross-country differences in the time devoted to personal care and sleep, although such differences seem to compensate for each other, leading to no significant differences in general personal care. Furthermore, individuals in Italy devote less time to market work but more time to non-market work, which leads to a gap in leisure time favouring Italy compared to the other countries, while people living in Germany appear to have less leisure time than their European neighbours.

The two countries with the highest average time devoted to sleep are France and the Netherlands, while the two countries with the lowest time devoted to sleep are Germany and Italy. Regarding personal care, the countries with the highest average time devoted to this activity are Germany and Italy, while those with the lowest time devoted to this are the Netherlands and the United Kingdom. If we consider a category of general personal care, that includes sleep and other personal care, it seems that individuals in the countries with more time spent in sleep also devote less time to other personal care, which may result in no differences across countries in the time devoted to general personal care.

\footnotetext{
${ }^{6}$ The empirical analysis done in this paper shows a dependence of health status on age. Thus, we have alternatively adjusted all the time use variables by age. To that end, we have built weights for each country, considering the proportion of individuals in the age ranges of 21-29, 30-39, 40-49, 50-59, 60-64, and compute the proportion of individuals in each age range. Using these latter proportions, we compute the age weights as the percentage of individuals in each age range. That way, if we apply these weights, we would be considering the distribution of time taking into account the age structure of the population in the survey. We have computed the summary statistics of the different uses of time, by country, gender, and self-reported health status, using the age weights. Comparing these results with the main results of the paper, we observe that there are very little differences in terms of statistical significance. The only difference is found in personal care and non-market work of men in Germany. We find no differences in terms of statistical significance for women. Results are available upon request.

${ }^{7}$ These weights (PROPWT) are computed to take into account the distribution of the population and days of the week, and thus all the days of the week are equally represented in the sample. To promote consistency among the datasets, and to prevent surveys from countries with larger populations swamping the surveys from countries with smaller populations, original survey weights are deflated in the computation of PROPWT. More information on how weights are computed can be found in http://www.timeuse.org/sites/ctur/files/858/mtus-user-guide-r6-july-2013.pdf
} 
Regarding the time devoted to market work, here we must remember that we include individuals who are both working and non-working, and thus cross-country differences in Labour Force Participation (LFP) may drive cross-country differences in the time devoted to this activity. Also, differences in part-time employment rates may help to explain such cross-country differences. However, differences in the time devoted to market work are small in general, and we cannot discern any differential pattern across countries. The only exception is Italy, where individuals devote more time to these activities compared to the other countries. Considering the time devoted to non-market work, we observe large differences across countries. The countries with the most time devoted to this activity by women are Italy and Spain, while those same countries show the least time devoted to this activity by men. For the remaining countries, there are no significant differences in the gender distribution of non-market work. These results are consistent with existing research finding that Mediterranean countries are the most inegalitarian countries (among developed countries) regarding the gender distribution of household labour (Sevilla, 2010; Gimenez-Nadal et al., 2012).

Considering the time devoted to leisure, we observe a large difference between the Netherlands and Spain, and the rest of analyzed countries, with these two countries having more leisure time than the others. Individuals from Italy appear to have less leisure time compared to their European neighbours. The fact that individuals in the Netherlands have more leisure compared to individuals in France and the United Kingdom is consistent with Gimenez-Nadal and Sevilla (2012). Furthermore, while we find that the dispersion in leisure across countries is smaller for men, in the case of women it is larger. This may be due to cross-country differences in social norms regarding the gender distribution of total work, defined as the sum of market and nonmarket work time (Burda et al., 2012). Additionally, differences in LFP across the countries, especially for women, may also help to explain such differences in leisure time.

Podor and Halliday (2012) analyze the age-profile of time use for single and married people in the ATUS. In the same spirit, we have analyzed the relationship between selfreported health status and age, to see how perceived health varies with age. Figures 2-A and 2-B show the average self-reported health status of men and women, respectively, by age of respondent. We have computed the average value of the variable of selfreported health status for respondents at each age of reference, for both men and 
women. It can be observed that self-reported health decreases with age, as older individuals report worse health status. This negative association between health status and age can be linked to evidence on the relationship between health status and time allocation decisions. If health decreases with age, we can expect that, as individuals grow older, they increase their time devoted to sleep, personal care, non-market work, and leisure, while they decrease the time devoted to market work.

Tables 1-A and 1-B shows for each country, gender and self-reported health status the time devoted to the five time use activities, the difference in the time devoted to the reference activity between individuals reporting "very good health" and "poor health”, and the p-value of the difference. A positive value of the difference indicates that individuals who report having "poor health” devote less time to the reference activity compared to individuals with "very good health". Negative values of the difference indicate that individuals who report having "poor health" report more time spent in the reference activity, compared to individuals with "very good health". A p-value lower than .05 indicates that the difference between individuals reporting "poor health" and "very good health" in the overall time devoted to the reference activity is statistically significant at standard levels. We observe clear patterns for the relationship between health status and the time devoted to the five activities in all the countries, consistent with the conclusions obtained from Figures 1-A and 1-B. ${ }^{8}$

As shown in Table 1-A, the difference in the hours per day devoted to sleep between men reporting "poor health" and those reporting "very good health" is -1.282, -0.383, 1.307, -1.316, -1.199 and -0.582 hours per day in France, Germany, Italy, the Netherlands, Spain, and the United Kingdom, respectively. For the hours per day devoted to personal care, the difference between the two groups of individuals is -0.686 , $-0.159,-0.503,-0.291,-0.374$ and -0.435 , while the difference in non-market work is 0.432, $-0.353,-0.722,-1.998,-0.737$ and -0.772 in France, Germany, Italy, the Netherlands, Spain, and the United Kingdom, respectively. Regarding the time devoted to leisure, the difference in hours per day between the two groups is $-1.218,-1.092$, 1.116, $-2.578,-1.851$ and -3.304 , while for market work the difference is $3.618,1.983$, 3.649, 6.184, 4.161 and 5.142 in France, Germany, Italy, the Netherlands, Spain, and the United Kingdom, respectively.

\footnotetext{
${ }^{8}$ We have also computed the difference between individuals reporting "very good health" and other health statuses (e.g., "fair health”, "good health”), and in all cases the differences are statistically significant, results are available upon request.
} 
The difference in the hours per day devoted to sleep between women reporting "poor health" and those reporting "very good health" is $-1.352,-0.378,-0.896,-1.416,-0.936$ and -0.585 in France, Germany, Italy, the Netherlands, Spain, and the United Kingdom, while the difference in personal care is $-0.523,-0.353,-0.345,-0.282$ and -0.344 in France, Germany, the Netherlands, Spain, and the United Kingdom, respectively. For the time devoted to non-market work, the difference between the two groups in the hours per day devoted to this activities is $-0.453,-0.746$, and -0.665 in France, Italy and Spain, the difference in leisure is $-0.724,-0.456,-0.286,-1.034,-0.596$ and -1.850 , and in the time devoted to market work, the difference is 3.052, 1.428, 1.853, 2.926, 2.480 and 2.954 hours per day in France, Germany, Italy, the Netherlands, Spain, and the United Kingdom, respectively.

Considering the patterns of changes across health statuses of men in the time devoted to our five time use activities, we can sort the countries into three groups. In the first group, composed of France, Italy, and Spain, the differences in the time devoted to sleep, personal care, and market work between individuals with "poor health" and "fair health" are large, while the differences between individuals with "fair health”, "good health" and "very good health" are small. In the second group, composed of Germany and the United Kingdom, the gradient between health and the time devoted to these activities is smooth (i.e. the differences between consecutive health groups are very similar). The Netherlands stands alone in that the largest difference is found between individuals with "good health" and "very good health". We cannot establish any clear pattern in the negative relationship between health status, on the one hand, and the time devoted to non-market work and leisure and, in the case of women, we cannot sort these countries in the same way.

\section{EMPIRICAL STRATEGY}

We estimate lineal regressions on the time devoted to sleep, personal care, market work, non-market work, and leisure. However, since we observe a high proportion of "zeros" for some of these activities, such as market and non-market work (overall, on 48 and 11 per cent of the days, respectively, individuals reported no time devoted to these), there can be some controversy regarding the selection of alternative models, such as that of Tobin (1958). According to Frazis and Stewart (2012), linear models are preferred in the analysis of time allocation decisions, and Gershuny (2012) argues that traditional 
diary studies can still produce accurate estimates of mean times in activities for samples and subgroups. Foster and Kalenkoski (2013) compare the use of Tobit and linear models in the analysis of the time devoted to childcare activities, finding that the qualitative conclusions are similar for the two estimation methods. We rely on linear regressions, although results using the Tobit model are consistent and available upon request.

Furthermore, we take into account that the time individuals spend in any activity (e.g., market work) cannot be devoted to any of the other activities. The time constraint binds at 24 hours per day, and individuals must decide how much time they devote to the different activities, which leads to substitution or complementarity effects between groups of activities. Thus, we need to take into account that the more time individuals devote to any one activity, the less time is available for the others. However, we cannot use individual time in any specific activity as an explanatory variable of other uses of time, since it would lead to endogeneity problems, and for this reason we estimate a Seemingly Unrelated Regression (SUR) system on the time devoted to sleep, personal care, market work, non-market work, and leisure.

The statistical model is as follows. For a given individual ' $\mathrm{i}$ ' and country “ $\mathrm{j}$ ” $(\mathrm{j}=1,2 \ldots 5)$, let $S_{i j}, P C_{i j}, M W_{i j}, N M W_{i j}$ and Leisure $i j$ represent the daily hours that the individual reports performing sleep, personal care, market work, non-market work, and leisure. Let $X_{i j}$ be a vector of socio-demographic characteristics, and let $\varepsilon_{s i j}, \varepsilon_{p c i j}$, $\varepsilon_{m w i j}$, $\varepsilon_{n m w i j}$ and $\varepsilon_{l i j}$ be random variables that represent unmeasured factors. We estimate the following equations:

$$
\begin{aligned}
& S_{i j}=\alpha_{s}+\beta_{s 1} S A H S_{i j}+\beta_{s 2} X_{i j}+\alpha_{s} \text { Day }_{i j}^{n}+\delta_{s} \text { Month }_{i j}^{k}+\varepsilon_{s i j} \\
& P C_{i j}=\alpha_{p c}+\beta_{p c 1} S A H S_{i j}+\beta_{p c 2} X_{i j}+\alpha_{p c} \text { Day }_{i j}^{n}+\delta_{p c} \text { Month }_{i j}^{k}+\varepsilon_{p c i j} \\
& M W_{i j}=\alpha_{m w}+\beta_{m w 1} S A H S_{i j}+\beta_{m w 2} X_{i j}+\alpha_{m w} \text { Day }_{i j}^{n}++\delta_{m w} M \text { onth }_{i j}^{k}+\varepsilon_{m w i j} \\
& N M W_{i j}=\alpha_{n m w}+\beta_{n m w 1} S A H S_{i j}+\beta_{n m w 2} X_{i j}+\alpha_{n m w} \text { Day }_{i j}^{n}+\delta_{n m w} \text { Month }_{i j}^{k}+\varepsilon_{n m w i j} \\
& L_{i j}=\alpha_{l}+\beta_{l 1} S A H S_{i j}+\beta_{l 2} X_{i j}+\alpha_{l} \text { Day }_{i j}^{n}+\delta_{l} \text { Month }_{i j}^{k}+\varepsilon_{l i j}
\end{aligned}
$$

where $S A H S_{i j}$ is the variable indicating the self-reported health status of individual ' $\mathrm{i}$ ' in country “j”, $X_{i j}$ is a vector of personal and household characteristics, Day ${ }_{i j}^{n}$ is a vector of 
day-of-week dummy variables (ref.: Saturday, $\mathrm{n}=6$ ), and Month $_{i j}^{k}$ is a vector of month dummy variables (ref.: December, $\mathrm{k}=11$ ). These dummy variables take value " 1 ” if the diary of individual "i” in country " $\mathrm{j}$ " refers to the n-th day/k-th month, and " 0 " otherwise. Thus, reference diaries refer to Saturdays in December. In the case of the Netherlands, the survey was done during October only, and thus we do not include dummies to control for the month of the diary.

We allow for correlations in the unobserved determinants of the activities by allowing the error terms to be jointly normally distributed, with no restrictions on the correlation. This specification accounts for the time constraint that may require individuals to spend more time on one activity and, therefore, less time on another. We additionally assume that the error components are independent across individuals:

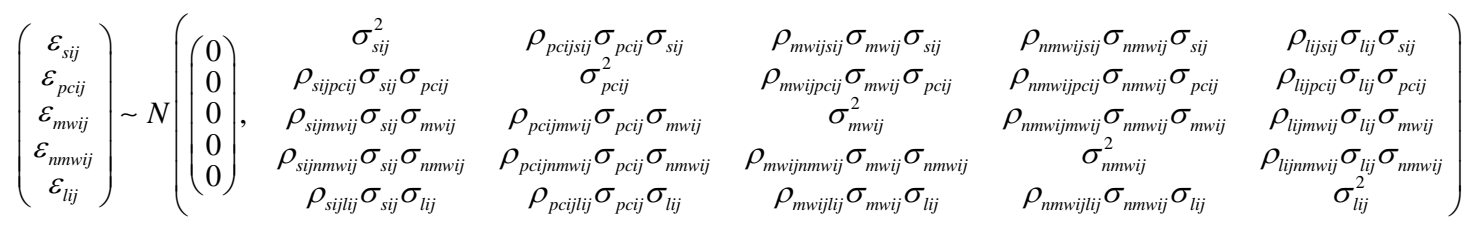

The vector $X_{i j}$ includes personal and household characteristics (Hallberg and Klevmarken, 2003; Kalenkoski et al., 2005, 2009; Kimmel and Connelly, 2007; Connelly and Kimmel, 2009; Gimenez-Nadal and Molina, 2013), which are age and its square, secondary and university education, the number of children under 18 in the household, household size, whether the youngest child is under 5 , whether the youngest child is $5-12$, whether the youngest child is $13-17$, and civil status (ref.: not in couple) ${ }^{9}$

One of the limitations of self-reported health status measures is that of comparability across individuals. Lindeboom and Van Doorslaer (2004) analyze cut-point and index shifts in self-reported health, and find that self-reported health is not perfectly comparable across individuals. Following Goryakin et al. (2013), as an alternative analysis we create the "good health" variable that takes value " 1 " if individuals reported “good” or "very good” health, and value "0” when individuals report “poor” and “fair” health, and include this dummy variable in Equations (1) to (5) as a measure of selfreported health.

\footnotetext{
${ }^{9}$ We do not include the labour status of respondents, as it may lead to endogeneity problems, since the labour status of individuals probably influences the time devoted to all activities. See Table A3 in the Appendix for summary statistics of the characteristics included in the regressions.
} 
We transform the dependent variable to its log form, because we can then directly obtain the relationship between the dependent and independent variables as changes in the dependent variables measured in percentage points. In the particular case of health status, a discrete variable, we can interpret that the dependent variable changes by $100 *$ (coefficient) percent for a one unit increase (i.e. changes from "poor health" to "fair health”, from “fair health” to "good health”, and from "good health” to "very good health”) in the independent variable, while all other variables in the model are held constant.

\section{RESULTS OF ESTIMATION}

Tables 2-A and 2-B show the SAHS and good health coefficients obtained from estimating Equations (1) to (5) on the time devoted to sleep, personal care, market work, non-market work, and leisure, for men and women respectively. ${ }^{10}$ Regarding results for men, we observe that in all countries, both the SAHS and the good health variables are associated with decreases in the time devoted to sleep, personal care, non-market work, and leisure, while they are associated with increases in the time devoted to market work, with these associations being statistically significant at standard levels. These results are consistent with the results obtained by Podor and Halliday (2012) for market work and leisure in the US, but not for non-market work, given that the authors find that better health is associated with large positive effects on home production.

In particular, and focusing on the SAHS variable, an increase of one category in the health status of men is associated with decreases in the time devoted to sleep of 2.7, 1.6, 1.5, 3.1, 2.4 and 1.4 percent in France, Germany, Italy, the Netherlands, Spain, and the United Kingdom, respectively, with respective decreases in the time devoted to personal care of 3.2, 1.1, 4.0, 1.3 and 1.0 percent, in the time devoted to non-market work of 2.9, 3.8, 3.6, 10.3, 5.5 and 5.2 percent, and in the time devoted to leisure of 3.7, 2.4, 6.9, 5.9 and 10.2 percent.

We observe that the strongest associations between health status and the time devoted to sleep and personal care are found in France, the Netherlands, and Spain, while the strongest associations between health status and the time devoted to market work, non-market work, and leisure are found in the Netherlands, Spain, and the United

\footnotetext{
${ }^{10}$ We do not show the coefficients for other controls (age, education, children, day of the week); they are available
} upon request. 
Kingdom. The weakest associations between health status and the time devoted to all activities are found in Italy and Germany. These differences point toward a three-group classification of countries based on results for men: one group that includes the Netherlands, Spain, and the United Kingdom, another of Germany and Italy, and France in a group of its own.

Regarding results for women, we observe that, in all countries, both the SAHS and the good health variables are associated with decreases in the time devoted to sleep, personal care, and non-market work, while they are associated with increases in the time devoted to market work, with these associations being statistically significant at standard levels. These results are consistent with those obtained by Podor and Halliday (2012) for the US regarding market work, but not for non-market work and leisure. Exceptions to these patterns are found in Italy, where personal care and better health are positively related, and better health has a non-statistically significant association with the time devoted to market work. The results for the relationship between health status and the time devoted to leisure are mixed. In Italy, we find a positive association, a negative association in the United Kingdom, and no statistically significant associations for the other countries.

Specifically, an increase of one category in the health status of women is associated with decreases in the time devoted to sleep of 2.6, 1.3, 1.0, 3.8, 1.8 and 1.6 percent in France, Germany, Italy, the Netherlands, Spain, and the United Kingdom, respectively, with respective decreases in the time devoted to personal care of 2.2, 2.2, 2.1, 0.5 and 1.2 percent, decreases in the time devoted to non-market work of 1.9, 2.7, 2.4, 2.3, 1.0 and 1.8 percent, and with decreases in the time devoted to leisure of 1.2 and 3.9 percent in the Netherlands and the United Kingdom. An increase of one category in the health status of women is associated with an increase of 1.2 and 2.3 percent in the time devoted to personal care and leisure in Italy. Considering the reported associations between health status and the time devoted to all activities, we cannot obtain clear patterns to group countries according to such associations. If we focus on leisure, we three groups of countries: a general group of countries composed of France, Germany, the Netherlands and Spain, with Italy and the United Kingdom each standing alone.

We have additionally estimated the associations between health status and the time devoted to non-market work and leisure by decomposing each activity in several sub- 
categories (results are shown in Tables A4 and A5 of the Appendix). ${ }^{11}$ For non-market work we consider "housework", “childcare”, "shopping” and "other housework”, and for leisure we consider "TV watching”, “out of home leisure”, "reading/listening”, "other leisure” and "civic/voluntary”. For men, the channels through which better health is related to less time in non-market work are housework, shopping, and other housework, while childcare time seems to be non-sensitive to the health status of men. In the case of leisure, the channels through which better health is related to less time in these activities are TV watching and other leisure. In the case of women, the channel through which better health is related to less time in non-market work is housework, while for leisure we observe that better health is related to less time watching TV, but more time reading/listening and out of home leisure.

Finally, Tables 3-A and 3-B show, for each country and gender, the correlation matrix of residuals from estimating Equations (1) to (5) using the SAHS variable. According to Table 3-A, men show negative correlations between market work and the other activities, especially for non-market work and leisure. The correlation of residuals between market work and non-market work is $-0.47,-0.49,-0.43,-0.50,-0.44$ and -0.50 for France, Germany, Italy, the Netherlands, and the United Kingdom, respectively, and the correlation of residuals between market work and leisure is $-0.63,-0.49,-0.59$, 0.50, -0.63 and -0.60 . Smaller negative correlations are found between market work, on the one hand, and sleep and personal care on the other. Personal care and sleep have very small correlations, and we find a positive correlation between personal care and sleep, on the one hand, and non-market work on the other, although these also are very small. For the remaining relationships, we find mixed evidence.

For women, we obtain negative correlations between market work and the other activities, especially for non-market work and leisure. The correlation of residuals between market work and non-market work is $-0.62,-0.47,-0.58,-0.50,-0.52$ and -0.53 , and between market work and leisure is $-0.55,-0.44,-0.46,-0.46,-0.53$ and -0.52 for France, Germany, Italy, the Netherlands and the United Kingdom, respectively. Smaller negative correlations are found between market work, on the one hand, and sleep and personal care on the other. Small negative correlations are found between sleep, on the one hand, and personal care, non-market work and leisure, on the other. Non-market

\footnotetext{
${ }^{11}$ See Table A2 for a description of the activities included in each time use category.
} 
work appears to be positively correlated with personal care, and negatively correlated with leisure.

\section{CONCLUSIONS}

This paper analyzes the relationship between health status and time allocation decisions in six European countries. Using the Multinational Time Use Study, we find that a better perception of own health is associated with less time devoted to sleep, personal care, and non-market work, and with less time in leisure for men, while it is associated with more time in market work. We also find that the relationship across activities is very similar across countries, and that market work has a relationship of substitution with sleep, personal care, non-market work, and leisure, with mixed evidence for the other relationships. Endogeneity issues may affect the estimated relationship between health and time allocation decisions, and thus the approach adopted here is very descriptive, and we cannot talk about causations, but only about relationships. Our conclusions differ from those of Podor and Halliday (2012) for the US, which may indicate that the relationship between health and time allocation decisions is countryspecific.

Several factors may affect the relationship between health status and time allocation decisions. García-Gomez (2011) shows that there is a significant effect running from health to the probability of employment, and that cross-country differences in Social Security arrangements may help to explain differences in the estimates for the effects of health shocks, such as differences in mechanisms of early retirement or disability policies. Although we can discern general patterns from our analysis, we find differences in the size of these relationships, especially for women. To the extent that time allocation decisions seem to be less dependent on health status for women, especially in the case of leisure, social norms may underlie the relationship, and may help to explain cross-country differences (Burda et al. 2012). In Mediterranean countries, more entrenched gender roles may lead to time allocation decisions being less dependent on health status. Apps and Rees (2005) argue that tax treatment of the female partner helps to explain cross-country differences in time allocation decisions over the life-cycle, and we show that self-assessed health varies with age, and thus tax systems may also help to explain gender and cross-country differences in the relationship 
between health and time allocations decisions. All these factors are worthy of analysis in future research.

Additionally, we find that different countries exhibit differences between males and females in the relationship between health status and time allocation decisions, which can be explained according to several factors. The first is gender differences in labour force participation, as countries differ in the participation rates of males and females in the labour market (EUROSTAT, 2013). If women participate less in the labour market in some countries, such as Italy, the effect of health status on market work can be relatively lower than in other countries. Alternatively, cross-country differences in social norms regarding the role of men and women in society may help to explain differences in this relationship. Countries differ in the extent to which males and females are involved in both the labour market and home (Sevilla, 2010; GimenezNadal et al., 2012; Gimenez-Nadal and Molina, 2014), which may influence the relationship between health and the time devoted to both market and non-market work. The study of the extent to which these factors affect the relationship between health and time allocation decisions may be relevant for policy issues.

Our paper will be of interest for economists and policymakers. To the extent that leisure time has value (as studies measuring instant satisfaction have shown, e.g. Kahneman and Krueger, 2006), the evidence presented in this paper provides a promising line of research for understanding cross-country differences in well-being. Additionally, since unhealthy people work less, our results help to explain a possible source of income inequality, both at the individual and the country level. These issues are important, and we argue that health is an important factor to consider in future research.

One limitation of our analysis is that our data is a cross-section of individuals, and it does not allow us to identify the effect of health net of (permanent) individual heterogeneity in preferences. This is particularly important in our context, as health may be endogenous to time allocation decisions. We cannot speak definitively about a causal relationship between health and individual time allocation decisions, and more research on this topic is needed. At present, there are no panels of time-use surveys currently available. Alternative datasets with a panel data structure, such as the British Household Panel Survey or the Panel Study of Income Dynamics, which also have information on housework and market work time, could be used to investigate this topic. Stylized 
questions on housework time, as in these surveys, have been confirmed as less reliable than the diary information used here (Juster and Stafford 1985; Robinson and Godbey 1997). Moreover, these surveys have no information about other uses of time, such as leisure

\section{REFERENCES}

Aguiar, M. and E. Hurst (2007). "Measuring trends in leisure: The allocation of time over five decades," Quarterly Journal of Economics 122, 969-1007.

Anderson, K.H., and R.V. Burkhauser (1985). "The retirement-health nexus: a new measure of an old puzzle,” Journal of Human Resources 20, 321-330

Apps, P., and R. Rees (2005). "Gender, time use, and public police over the life cycle,” Oxford Review of Economic Policy 21: 439-461.

Au, D., T. Crossley and M. Schellhorn (2005). "The effects of health shocks and longterm health on the work activity of older Canadians," Health Economics 14, 9991018.

Bago d’Uva, T., E. Van Doorslaer, M. Lindeboom, and O. O’Donnell (2008). "Does Reporting Heterogeneity Bias the Measurement of Health Disparities?” Health Economics 17: 351-375.

Barnay, T. (2010). "In which ways do unhealthy people older than 50 exit the labour market in France?” European Journal of Health Economics 11, 127-140

Bazzoli, G. J. (1985). "The Early Retirement Decision: New Empirical Evidence on the Influence of Health,” Journal of Human Resources 20: 215-234.

Benitez-Silva, H., M. Buchinsky, H.M Chan, S. Cheidvasser and J. Rust (2004). "How large is the bias in self-assessed disability?" Journal of Applied Econometrics 19, 649-670.

Bianchi, S.M., M.A. Milkie, L.C. Sayer, and J.P. Robinson (2000) "Is Anyone Doing the Housework? Trends in the Gender Division of Household Labor," Social Forces 79: 191-228.

Biddle, J., and D. Hamermesh (1990). "Sleep and the allocation of time," Journal of Political Economy 98: 922-943.

Bonke, J. (2005). "Paid work and unpaid work. Diary information versus questionnaire information,” Social Indicators Research 70: 349-368.

Burda, M., D. Hamermesh and P. Weil (2008). "The Distribution of Total Work in the US and EU," in Working Hours and Job Sharing in the EU and USA: Are Americans Crazy? Are Europeans Lazy? Boeri, Burda and Kramarz (eds.), Oxford Univ. Press.

Burda, M., D. Hamermesh and P. Weil (2012). "Total work and gender: facts and possible explanations,” Journal of Population Economics 26: 239-261.

Bound, J. (1991). "Self-reported versus objective measures of health in retirement models,” Journal of Human Resources 26, 106-138. 
Cai, L., and G. Kalb (2006). "Health status and labour force participation: evidence from Australia,” Health Economics 15, 241-261.

Chirikos, T. N., and Nestel (1984). "Economic Determinants and Consequences of SelfReported Work Disability,” Journal of Health Economics 3: 117-136.

Connelly, R., and J. Kimmel (2009). "Spousal influences on parents' non-market time choices," Review of Economics of the Household 7: 361-394.

Crossley, T.F., and S. Kennedy (2002). “The reliability of self-assessed health status," Journal of Health Economics 21, 643-658.

Currie, J., and B. Madrian (1999). "Health, Health Insurance and the Labor Market,” in Handbook of Labor Economics, Vol 3, Ashenfelter and Card (Eds.), Elsevier: Amsterdam.

Cutler, D. M., E.L. Glaeser and J.M. Shapiro (2003). "Why have Americans become more obese?” Journal of Economic Perspectives 17: 93-118.

Deaton, A.S., and C.H. Paxson (1998). “Ageing and inequality in income and health,” American Economic Review, Papers and Proceedings 88, 248-253.

Disney, R., C. Emmerson and M. Wakefield (2006). "Ill health and retirement in Britain, A panel data-based analysis,” Journal of Health Economics 25, 621-649.

Dwyer, D.S., and O.S. Mitchell (1999). "Health problems as determinants of retirement: are self-rated measures endogenous?” Journal of Health Economics 18, 173-193

Ettner, S.L. (1996). "New evidence on the relationship between income and health," Journal of Health Economics 15, 67-85.

EUROSTAT (2013). Statistics, http://epp.eurostat.ec.europa.eu/portal/page/portal/statistics/themes

Fisher, K., M. Egerton, J. Gershuny, and J. Robinson (2007). "Gender Convergence in the American Heritage Time Use Study," Social Indicators Research 82: 1-33.

Fisher K, Gershuny J, Gauthier A (2011) Multinational Time Use Study: User's Guide and Documentation. http://www.timeuse.org/files/cckpub/858/mtus-userguide-r4.pdf. Accessed 1 September 2012.

Foster, G., and C. Kalenkoski (2013). "Tobit or OLS? An empirical evaluation under different diary window lengths,” Applied Economics 45: 2994-3010.

Frazis, H., and J. Stewart (2012). "How to Think About Time-Use Data: What Inferences Can We Make About Long- and Short-Run Time Use from Time Use Diaries?” Annals of Economics and Statistics 105/106: 231-246.

Garcia-Gómez, P. (2011). "Institutions, health shocks and labour outcomes across Europe,” Journal of Health Economics 30: 200-213.

Gauthier, A., T.M. Smmeding, and F.F.J. Furstenberg (2004). "Are parents investing less in children? Trends in selected industrialized countries," Population and Development Review 3: 647-671.

Gershuny, J. (2000). Changing times, work and leisure in post industrial society. Oxford: Oxford University Press.

Gershuny, J.I. (2009). "Veblen in Reverse: Evidence from the Multinational Time-Use Archive,” Social Indicators Research 93: 37-45. 
Gershuny, J.I. (2012). “Too Many Zeros: A Method for Estimating Long-term Time-use from Short Diaries,” Annals of Economics and Statistics 105/106: 247-270.

Gershuny, J.I. (2013). "National Utility: Measuring the Enjoyment of Activities," European Sociological Review 29: 996-1009.

Gershuny, J., and O. Sullivan (2003). "Time use, gender, and public policy regimes," Social Politics: International Studies in Gender, State and Society 10: 205-228.

Gimenez-Nadal, J.I., and J.A. Molina (2013). "Parents' Education as a Determinant of Educational Childcare Time,” Journal of Population Economics 26: 719-749.

Gimenez-Nadal, J.I., and J.A. Molina (2014). "Regional unemployment, gender, and time allocation of the unemployed," Review of Economics of the Household 12: 105127.

Gimenez-Nadal, J.I, and R. Ortega (2013). "Health status and time allocation in Spain,” Applied Economics Letters 20: 1435-1439.

Gimenez-Nadal, J.I., and A. Sevilla (2011). “The Time-Crunch Paradox,” Social Indicators Research 102: 181-196.

Gimenez-Nadal, J.I., and A. Sevilla (2012). "Trends in time allocation: A cross-country analysis,” European Economic Review 56: 1338-1359.

Gimenez-Nadal, J.I., A. Sevilla, and J.A. Molina (2012). "Social Norms, Partnerships and Children," Review of Economics of the Household 10: 215-236.

Goryakin, Y., L. Rocco, M. Suhrcke, B. Roberts and M. McKee (2013): “The effect of health on labour supply in nine former Soviet Union countries," European Journal of Health Economics, forthcoming.

Gronau, R. (1980). "Home production - a forgotten industry," Review of Economics and Statistics 62: 408-416.

Grossman, M. (1972a). "On the concept of health capital and the demand for health," Journal of Political Economy 80, 223-255.

Grossman, M. (1972b). The Demand for Health: A Theoretical and Empirical Investigation (Columbia University Press for the National Bureau for Economic Research).

Guryan, J., E. Hurst, and M. Kearney (2008). "Parental education and parental time with children,” Journal of Economic Perspectives 22: 23-46.

Hallberg, D. (2003). "Synchronous leisure: Jointness and household labour supply," Labour Economics 10: 185-203.

Hallberg, D., and A. Klevmarken (2003). „Time for children: A study of parent's time allocation,” Journal of Population Economics 16: 205-226.

Hamermesh, D. (2002). “Timing, togetherness and time windfalls," Journal of Population Economics 15: 601-623.

Haveman, R., B. Wolfe, B. Kreider and M. Stone (1994). "Market Work, Wages, and Men's Health,” Journal of Health Economics 13: 163-182.

Hook, J.L. (2006). “Care in Context: Men’s Unpaid Work in 20 Countries, 19652003,” American Sociological Review 71, 639-60. 
Jones. A., N. Rice and Roberts (2010). "Sick of work or too sick to work? Evidence on self-reported health shocks and early retirement from the BHPS," Economic Modelling 27, 866-880.

Juster, T., and F.P. Stafford (1985). Time, Goods, and Well-Being. Ann Arbor, MI: Institute for Social Research.

Jürges, H. (2007). "True Health vs Response Styles: Exploring Cross-Country Differences in Self-Reported Health,” Health Economics 16: 163-178.

Kahneman, D. and A.B. Krueger (2006). "Developments in the Measurement of Subjective Well-Being,” Journal of Economic Perspectives 20, 3-24.

Kahneman, D., A.B. Krueger, D. Schkade, N. Schwarz and A. Stone (2004). "A Survey Method for Characterizing Daily Life Experience: The Day Reconstruction Method," Science 3, 1776-1780.

Kalenkoski, C., D. Ribar and L. Stratton (2005). "Parental Childcare in Single Parent, Cohabiting, and Married Couple Families: Time-Diary Evidence from the United Kingdom,” American Economic Review 95: 194-198.

Kalenkoski, C., D. Ribar, and L. Stratton (2009). “The influence of wages on parents' allocations of time to child care and market work in the United Kingdom,” Journal of Population Economics 22: 399-419.

Kerkhofs, M., and M. Lindeboom (1995). "Subjective Health Measures and State Dependent Reporting Errors,” Health Economics 4, 221-235.

Kimmel, J., and R. Connelly (2007). "Mothers' Time Choices: Caregiving, Leisure, Home Production, and Paid Work,” Journal of Human Resources 42: 643-661.

Klevmarken, N.A. (2005). "Estimates of a labour supply function using alternative measures of hours of work," European Economic Review 49: 55-73.

Kreider, B. (1999). "Latent work disability and reporting bias," Journal of Human Resources 34, 734-769.

Krueger, A.B. (2007). “Are We Having More Fun Yet? Categorizing and Evaluating Changes in Time Allocation,” Brookings Papers on Economic Activity 2, 193-217.

Lindeboom, M., and E. Van Doorslaer (2004). "Cut-point shift and index shift in selfreported health,” Journal of Health Economics 23: 1083-1099.

Lindeboom, M., and M. Kerkhofs (2009). "Health and Work of the Elderly: Subjective Health Measures, Reporting Errors and the Endogenous Relationship Between Health and Work," Journal of Applied Econometrics 24: 1024-1046.

Mullahy, J., and S.A. Robert (2010). "No time to lose: time constraints and physical activity in the production of health," Review of Economics of the Household 8: 409432.

Philipson, T., and R. Posner (2008). "Is the obesity epidemic a public health problem? A decade of research on the economics of obesity,” NBER w.p. 14010.

Podor, M., and T.J. Halliday (2012). "Health Status and the Allocation of Time," Health Economics 21, 514-527.

Robinson, J.P. and G. Godbey (1997). Time for Life: The Surprising Ways Americans Use their Time. University Park, Pennsylvania: The Pennsylvania State University Press. 
Sari, N. (2009). "Physical inactivity and its impact on healthcare utilization," Health Economics 18: 885-901.

Schneider, U., C. Pfarr, B. S. Schneider, and V. Ulrich (2012). "I feel good! Gender differences and reporting heterogeneity in self-assessed health," European Journal of Health Economics 13: 251-265.

Sevilla, A. (2010). "Household division of labour and cross-country differences in household formation rates,” Journal of Population Economics 23: 225-249

Sevilla, A., J.I. Gimenez-Nadal, and J.I. Gershuny (2012). "Leisure inequality in the United States: 1965-2003,” Demography 49: 939-964

Stern, S. (1989). "Measuring the effect of disability on labour force participation," Journal of Human Resources 24, 361-395.

Stiglitz, J., A. Sen and J.P. Fitoussi (2009). Report by the commission on the measurement of economic performance and social progress.

Tobin, J. (1958). "Estimation of relationships for limited dependent variables," Econometrica 26: 24-36.

US Department of Health and Human Services. (1996). "Physical activity and health: report of the surgeon general." Atlanta, GA, US: Department of Health and Human Services, CDC.

Yee-Kan, M. (2008). "Measuring housework participation: The gap between "stylised" questionnaire estimates and diary-based estimates," Social Indicators Research 86: 381-400. 
Figure 1-A.Time allocation and health status of respondents, males
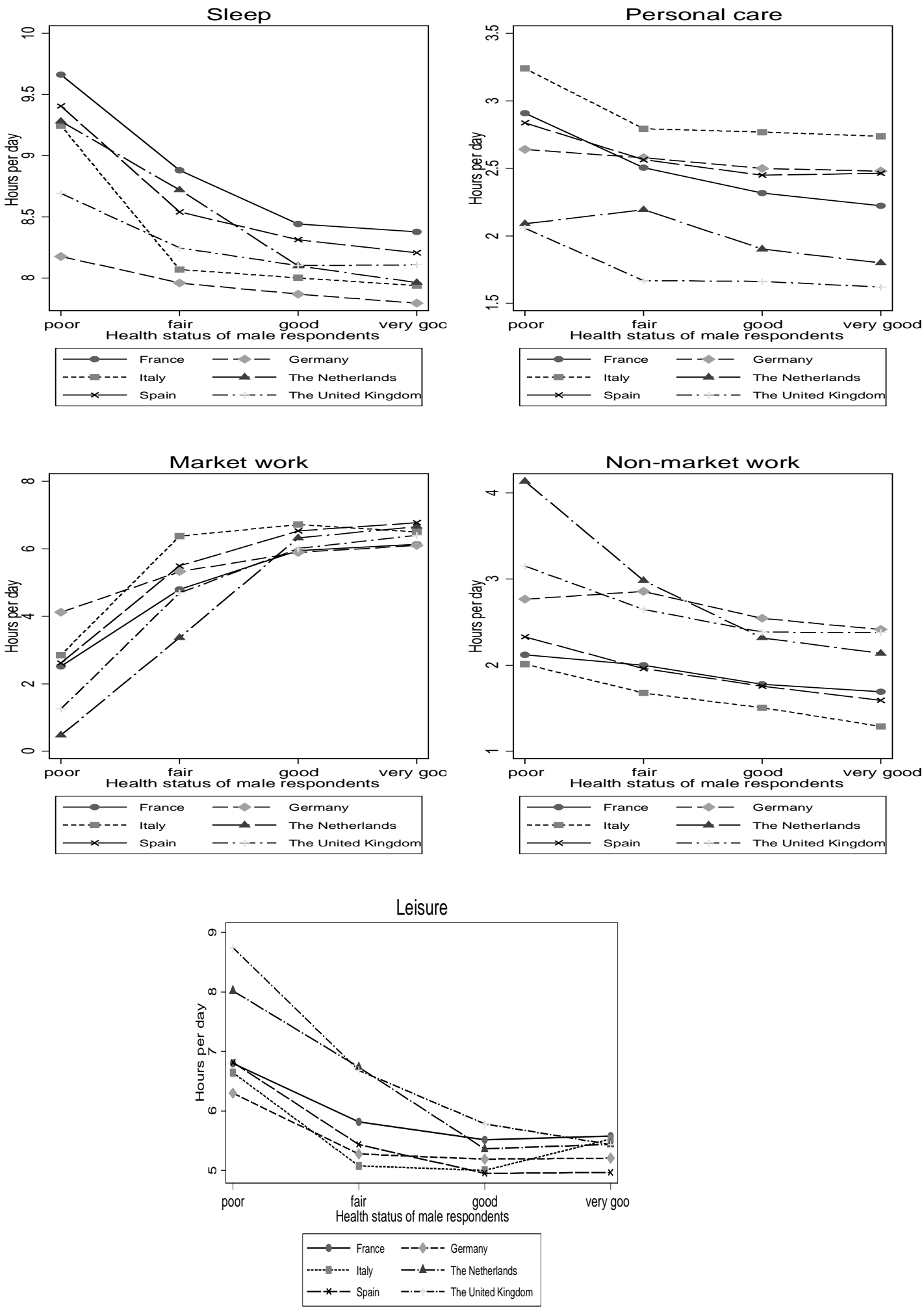

Notes: The sample is restricted to include non-retired/non-student individuals between the ages of 21 and 65 (inclusive) included in the Multinational Time Use Study (MTUS) from France, Germany, Italy, the Netherlands, Spain and the United Kingdom. Time use activities are measured in hours per day, see Table A2 for definitions of time-use categories. 
Figure 1-B.Time allocation and health status of respondents, females
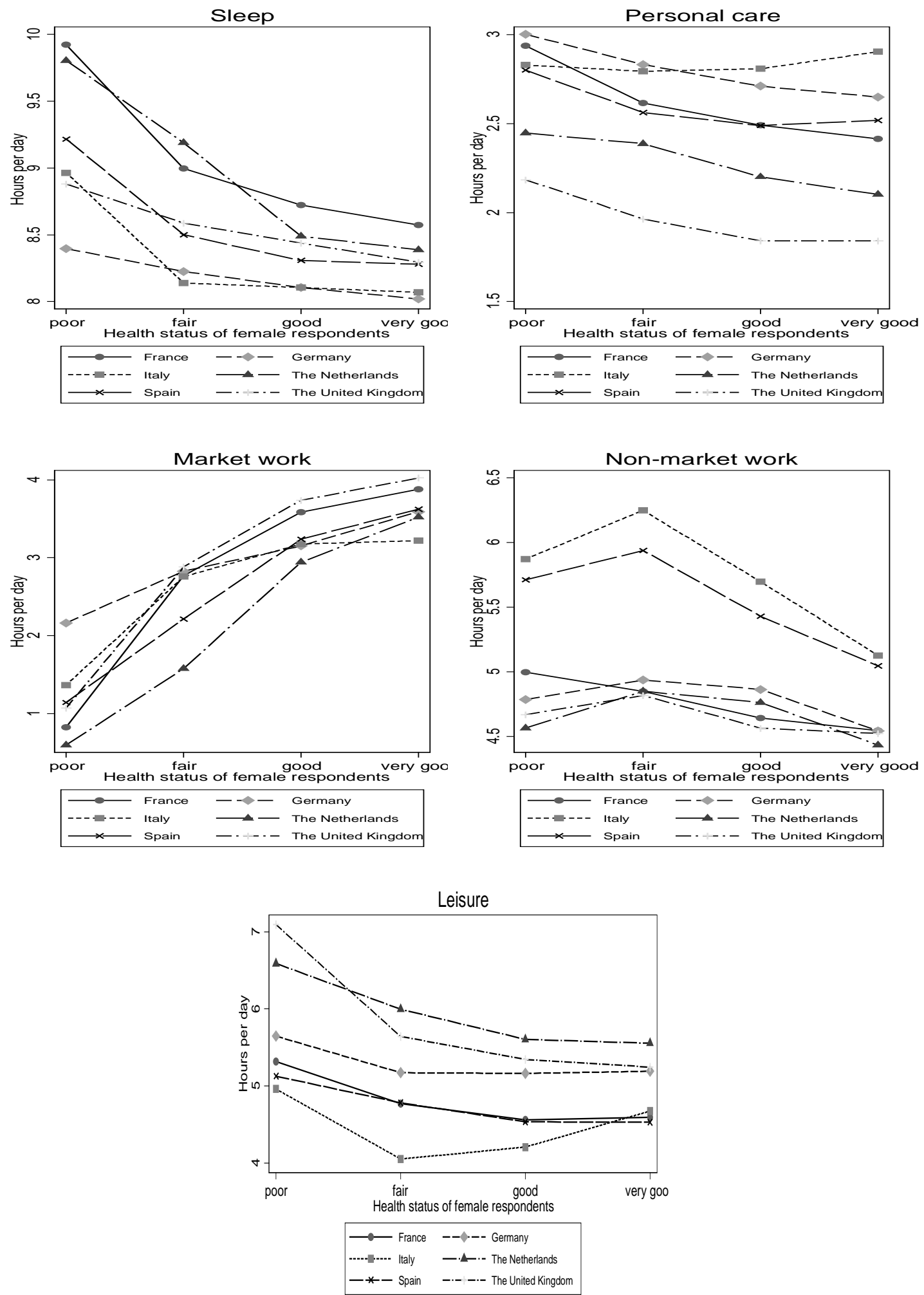

Notes: The sample is restricted to include non-retired/non-student individuals between the ages of 21 and 65 (inclusive) included in the Multinational Time Use Study (MTUS) from France, Germany, Italy, the Netherlands, Spain and the United Kingdom. Time use activities are measured in hours per day, see Table A2 for definitions of time-use categories. 
Figure 2-A. Health status by age of respondents, males

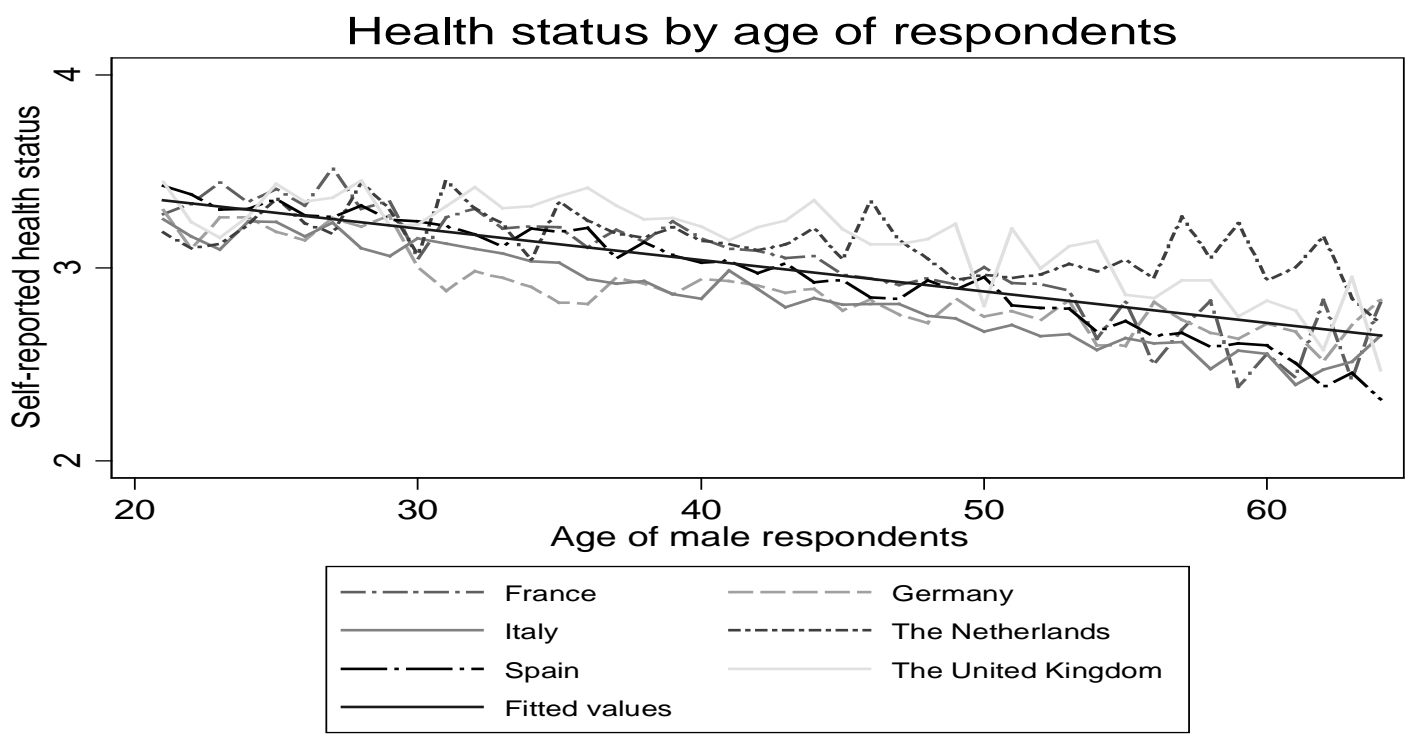

Notes: The sample is restricted to include non-retired/non-student individuals between the ages of 21 and 65 (inclusive) included in the Multinational Time Use Study (MTUS) from France, Germany, Italy, the Netherlands, Spain and the United Kingdom. Time use activities are measured in hours per day, see Table A2 for definitions of time-use categories.

Figure 2-B. Health status by age of respondents, females

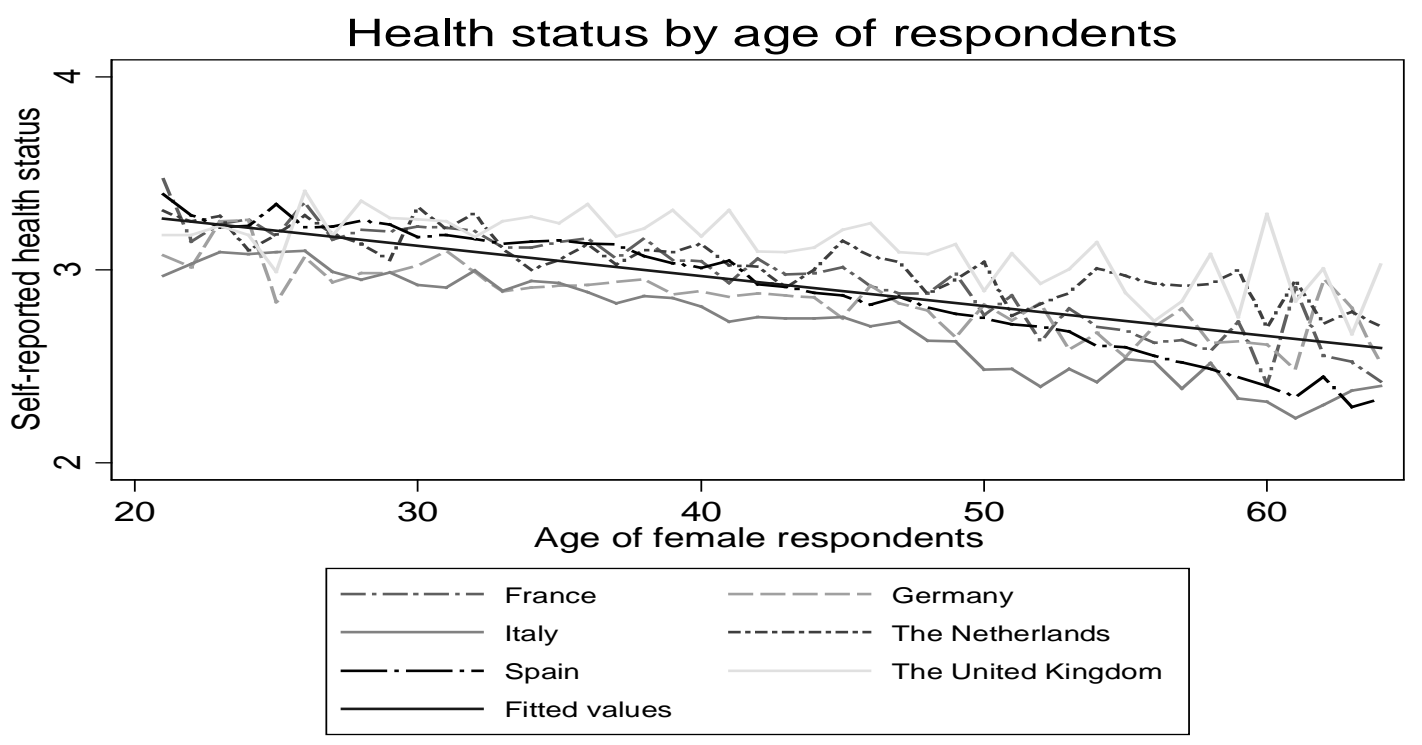

Notes: The sample is restricted to include non-retired/non-student individuals between the ages of 21 and 65 (inclusive) included in the Multinational Time Use Study (MTUS) from France, Germany, Italy, the Netherlands, Spain and the United Kingdom. Time use activities are measured in hours per day, see Table A2 for definitions of time-use categories. 
Table 1-A. Sum stats of time devoted to time use categories, by self-reported health status, males.

\begin{tabular}{|c|c|c|c|c|c|c|}
\hline Males & & $\begin{array}{r}\text { (1) } \\
\text { Sleep } \\
\end{array}$ & $\begin{array}{c}(2) \\
\text { Personal } \\
\text { Care } \\
\end{array}$ & $\begin{array}{c}\text { (3) } \\
\text { Market } \\
\text { work } \\
\end{array}$ & $\begin{array}{c}\text { (4) } \\
\begin{array}{c}\text { Non-Market } \\
\text { work }\end{array} \\
\end{array}$ & $\begin{array}{c}\text { (5) } \\
\text { Leisure } \\
\end{array}$ \\
\hline \multirow[t]{6}{*}{ France $(N=4,443)$} & Poor health & 9.662 & 2.909 & 2.511 & 2.120 & 6.798 \\
\hline & Fair Health & 8.883 & 2.504 & 4.799 & 1.999 & 5.815 \\
\hline & Good Health & 8.443 & 2.317 & 5.949 & 1.776 & 5.516 \\
\hline & Very Good Health & 8.380 & 2.223 & 6.129 & 1.689 & 5.580 \\
\hline & Diff Very Good Health-Poor Health & -1.282 & -0.686 & 3.618 & -0.432 & -1.218 \\
\hline & P-Value Difference & $(<0.01)$ & $(<0.01)$ & $(<0.01)$ & $(0.01)$ & $(<0.01)$ \\
\hline \multirow[t]{6}{*}{ Germany $(N=9,511)$} & Poor health & 8.179 & 2.639 & 4.116 & 2.766 & 6.300 \\
\hline & Fair Health & 7.961 & 2.578 & 5.321 & 2.857 & 5.278 \\
\hline & Good Health & 7.871 & 2.498 & 5.890 & 2.543 & 5.192 \\
\hline & Very Good Health & 7.796 & 2.480 & 6.099 & 2.413 & 5.207 \\
\hline & Diff Very Good Health-Poor Health & -0.383 & -0.159 & 1.983 & -0.353 & -1.092 \\
\hline & P-Value Difference & $(<0.01)$ & $(0.03)$ & $(<0.01)$ & $(0.02)$ & $(<0.01)$ \\
\hline \multirow[t]{6}{*}{ Italy $(N=13,155)$} & Poor health & 9.247 & 3.240 & 2.849 & 2.010 & 6.645 \\
\hline & Fair Health & 8.072 & 2.793 & 6.373 & 1.677 & 5.079 \\
\hline & Good Health & 8.003 & 2.769 & 6.717 & 1.505 & 5.002 \\
\hline & Very Good Health & 7.940 & 2.737 & 6.498 & 1.288 & 5.529 \\
\hline & Diff Very Good Health-Poor Health & -1.307 & -0.503 & 3.649 & -0.722 & -1.116 \\
\hline & P-Value Difference & $(<0.01)$ & $(<0.01)$ & $(<0.01)$ & $(<0.01)$ & $(<0.01)$ \\
\hline \multirow[t]{6}{*}{ The Netherlands $(N=7,155)$} & Poor health & 9.282 & 2.089 & 0.475 & 4.136 & 8.019 \\
\hline & Fair Health & 8.721 & 2.193 & 3.367 & 2.981 & 6.736 \\
\hline & Good Health & 8.100 & 1.901 & 6.318 & 2.316 & 5.363 \\
\hline & Very Good Health & 7.965 & 1.798 & 6.658 & 2.137 & 5.441 \\
\hline & Diff Very Good Health-Poor Health & -1.316 & -0.291 & 6.184 & -1.998 & -2.578 \\
\hline & P-Value Difference & $(<0.01)$ & $(0.07)$ & $(<0.01)$ & $(<0.01)$ & $(<0.01)$ \\
\hline \multirow[t]{6}{*}{ Spain $(N=13,198)$} & Poor health & 9.407 & 2.837 & 2.611 & 2.327 & 6.817 \\
\hline & Fair Health & 8.542 & 2.565 & 5.496 & 1.961 & 5.436 \\
\hline & Good Health & 8.314 & 2.449 & 6.528 & 1.756 & 4.953 \\
\hline & Very Good Health & 8.207 & 2.463 & 6.773 & 1.590 & 4.967 \\
\hline & Diff Very Good Health-Poor Health & -1.199 & -0.374 & 4.161 & -0.737 & -1.851 \\
\hline & P-Value Difference & $(<0.01)$ & $(<0.01)$ & $(<0.01)$ & $(<0.01)$ & $(<0.01)$ \\
\hline \multirow[t]{6}{*}{ The United Kingdom $(N=6,104)$} & Poor health & 8.692 & 2.055 & 1.255 & 3.150 & 8.741 \\
\hline & Fair Health & 8.248 & 1.668 & 4.689 & 2.648 & 6.683 \\
\hline & Good Health & 8.103 & 1.662 & 6.004 & 2.384 & 5.784 \\
\hline & Very Good Health & 8.110 & 1.620 & 6.397 & 2.378 & 5.437 \\
\hline & Diff Very Good Health-Poor Health & -0.582 & -0.435 & 5.142 & -0.772 & -3.304 \\
\hline & P-Value Difference & $(<0.01)$ & $(<0.01)$ & $(<0.01)$ & $(<0.01)$ & $(<0.01)$ \\
\hline
\end{tabular}

Notes: Standard deviations in parenthesis. The sample is restricted to include non-retired/non-student individuals between the ages of 21 and 65 (inclusive) included in the Multinational Time Use Study (MTUS) from France, Germany, Italy, the Netherlands, Spain and the United Kingdom. Time use activities are measured in hours per day, see Table A2 for definitions of time-use categories. Diff Very Good Health-Poor Health indicates the difference in the time devoted to the reference time use activity between individuals reporting "very good health", and individuals reporting "poor health", p-value of such difference in parentheses. 
Table 1-B. Sum stats of time devoted to time use categories, by self-reported health status, females.

\begin{tabular}{|c|c|c|c|c|c|c|}
\hline Females & & $\begin{array}{r}\text { (1) } \\
\text { Sleep } \\
\end{array}$ & $\begin{array}{c}(2) \\
\text { Personal } \\
\text { Care } \\
\end{array}$ & $\begin{array}{c}\text { (3) } \\
\text { Market work } \\
\end{array}$ & $\begin{array}{c}\text { (4) } \\
\begin{array}{c}\text { Non-Market } \\
\text { work }\end{array} \\
\end{array}$ & $\begin{array}{c}\text { (5) } \\
\text { Leisure } \\
\end{array}$ \\
\hline \multirow[t]{6}{*}{ France $(N=4,977)$} & Poor health & 9.924 & 2.938 & 0.826 & 4.996 & 5.315 \\
\hline & Fair Health & 8.997 & 2.617 & 2.768 & 4.848 & 4.770 \\
\hline & Good Health & 8.722 & 2.491 & 3.585 & 4.642 & 4.560 \\
\hline & Very Good Health & 8.572 & 2.415 & 3.878 & 4.543 & 4.592 \\
\hline & Diff Very Good Health-Poor Health & -1.352 & -0.523 & 3.052 & -0.453 & -0.724 \\
\hline & P-Value Difference & $(<0.01)$ & $(<0.01)$ & $(<0.01)$ & $(0.06)$ & $(<0.01)$ \\
\hline \multirow[t]{6}{*}{ Germany $(N=11,381)$} & Poor health & 8.398 & 3.002 & 2.164 & 4.785 & 5.647 \\
\hline & Fair Health & 8.225 & 2.832 & 2.828 & 4.936 & 5.172 \\
\hline & Good Health & 8.106 & 2.711 & 3.152 & 4.863 & 5.163 \\
\hline & Very Good Health & 8.020 & 2.650 & 3.592 & 4.541 & 5.191 \\
\hline & Diff Very Good Health-Poor Health & -0.378 & -0.353 & 1.428 & -0.243 & -0.456 \\
\hline & P-Value Difference & $(<0.01)$ & $(<0.01)$ & $(<0.01)$ & $(0.13)$ & $(<0.01)$ \\
\hline \multirow[t]{6}{*}{ Italy $(N=14,371)$} & Poor health & 8.965 & 2.829 & 1.367 & 5.871 & 4.961 \\
\hline & Fair Health & 8.139 & 2.795 & 2.759 & 6.249 & 4.053 \\
\hline & Good Health & 8.105 & 2.809 & 3.176 & 5.696 & 4.208 \\
\hline & Very Good Health & 8.069 & 2.905 & 3.220 & 5.125 & 4.674 \\
\hline & Diff Very Good Health-Poor Health & -0.896 & 0.076 & 1.853 & -0.746 & -0.286 \\
\hline & P-Value Difference & $(<0.01)$ & $(0.24)$ & $(<0.01)$ & $(<0.01)$ & $(0.07)$ \\
\hline \multirow[t]{6}{*}{ The Netherlands $(N=10,691)$} & Poor health & 9.804 & 2.447 & 0.596 & 4.564 & 6.589 \\
\hline & Fair Health & 9.188 & 2.387 & 1.577 & 4.849 & 5.996 \\
\hline & Good Health & 8.489 & 2.201 & 2.943 & 4.761 & 5.605 \\
\hline & Very Good Health & 8.388 & 2.102 & 3.522 & 4.432 & 5.555 \\
\hline & Diff Very Good Health-Poor Health & -1.416 & -0.345 & 2.926 & -0.132 & -1.034 \\
\hline & P-Value Difference & $(<0.01)$ & $(<0.01)$ & $(<0.01)$ & $(0.56)$ & $(<0.01)$ \\
\hline \multirow[t]{6}{*}{ Spain $(N=15,425)$} & Poor health & 9.216 & 2.801 & 1.144 & 5.711 & 5.127 \\
\hline & Fair Health & 8.500 & 2.563 & 2.216 & 5.938 & 4.782 \\
\hline & Good Health & 8.307 & 2.489 & 3.241 & 5.428 & 4.535 \\
\hline & Very Good Health & 8.280 & 2.519 & 3.624 & 5.046 & 4.531 \\
\hline & Diff Very Good Health-Poor Health & -0.936 & -0.282 & 2.480 & -0.665 & -0.596 \\
\hline & P-Value Difference & $(<0.01)$ & $(<0.01)$ & $(<0.01)$ & $(<0.01)$ & $(<0.01)$ \\
\hline \multirow[t]{6}{*}{ The United Kingdom $(N=7,090)$} & Poor health & 8.879 & 2.185 & 1.071 & 4.668 & 7.094 \\
\hline & Fair Health & 8.587 & 1.964 & 2.882 & 4.816 & 5.643 \\
\hline & Good Health & 8.438 & 1.841 & 3.737 & 4.563 & 5.345 \\
\hline & Very Good Health & 8.295 & 1.841 & 4.025 & 4.523 & 5.245 \\
\hline & Diff Very Good Health-Poor Health & -0.585 & -0.344 & 2.954 & -0.145 & -1.850 \\
\hline & P-Value Difference & $(<0.01)$ & $(<0.01)$ & $(<0.01)$ & $(0.40)$ & $(<0.01)$ \\
\hline
\end{tabular}

Notes: Standard deviations in parenthesis. The sample is restricted to include non-retired/non-student individuals between the ages of 21 and 65 (inclusive) included in the Multinational Time Use Study (MTUS) from France, Germany, Italy, the Netherlands, Spain and the United Kingdom. Time use activities are measured in hours per day, see Table A2 for definitions of time-use categories. Diff Very Good Health-Poor Health indicates the difference in the time devoted to the reference time use activity between individuals reporting "very good health", and individuals reporting "poor health", p-value of such difference in parentheses. 
Table 2-A. Estimates of the effect of health status on various time use categories using MTUS data, males

\begin{tabular}{|c|c|c|c|c|c|c|c|c|c|c|}
\hline \multirow[b]{3}{*}{ Males } & \multirow{2}{*}{\multicolumn{2}{|c|}{ Sleep }} & \multirow{2}{*}{\multicolumn{2}{|c|}{$\begin{array}{lr}(3) & (4) \\
\text { Personal Care }\end{array}$}} & \multirow{2}{*}{\multicolumn{2}{|c|}{$\begin{array}{l}\text { (5) (6) } \\
\text { Market work }\end{array}$}} & \multirow{2}{*}{\multicolumn{2}{|c|}{$\begin{array}{c}(7) \quad(8) \\
\text { Non-Market work }\end{array}$}} & \multicolumn{2}{|c|}{ (9) $\quad$ (10) } \\
\hline & & & & & & & & & Leis & sure \\
\hline & SAHS & $\begin{array}{c}\text { GOOD } \\
\text { HEALTH }\end{array}$ & SAHS & $\begin{array}{c}\text { GOOD } \\
\text { HEALTH } \\
\end{array}$ & SAHS & $\begin{array}{c}\text { GOOD } \\
\text { HEALTH } \\
\end{array}$ & SAHS & $\begin{array}{c}\text { GOOD } \\
\text { HEALTH } \\
\end{array}$ & SAHS & $\begin{array}{c}\text { GOOD } \\
\text { HEALTH }\end{array}$ \\
\hline France $(N=4,443)$ & $\begin{array}{c}-0.027 * * * \\
(0.004)\end{array}$ & $\begin{array}{c}-0.051^{* * *} \\
(0.007)\end{array}$ & $\begin{array}{c}-0.032^{* * *} \\
(0.007)\end{array}$ & $\begin{array}{c}-0.062^{* * *} \\
(0.013)\end{array}$ & $\begin{array}{c}0.170^{* * *} \\
(0.019)\end{array}$ & $\begin{array}{c}0.337 * * * \\
(0.037)\end{array}$ & $\begin{array}{c}-0.029 * * \\
(0.013)\end{array}$ & $\begin{array}{c}-0.073^{* * *} \\
(0.024)\end{array}$ & $\begin{array}{c}-0.037^{* * *} \\
(0.011)\end{array}$ & $\begin{array}{c}-0.072^{* * *} \\
(0.021)\end{array}$ \\
\hline Germany $(N=9,511)$ & $\begin{array}{c}-0.016 * * * \\
(0.003)\end{array}$ & $\begin{array}{c}-0.019 * * * \\
(0.005)\end{array}$ & $\begin{array}{l}-0.006 \\
(0.005)\end{array}$ & $\begin{array}{l}-0.014^{*} \\
(0.007)\end{array}$ & $\begin{array}{c}0.085^{* * *} \\
(0.013)\end{array}$ & $\begin{array}{c}0.120 * * * \\
(0.021)\end{array}$ & $\begin{array}{c}-0.038 * * * \\
(0.010)\end{array}$ & $\begin{array}{c}-0.073^{* * *} \\
(0.015)\end{array}$ & $\begin{array}{c}-0.024 * * * \\
(0.007)\end{array}$ & $\begin{array}{c}-0.024^{* *} \\
(0.011)\end{array}$ \\
\hline Italy $(N=13,155)$ & $\begin{array}{c}-0.015^{* * *} \\
(0.003)\end{array}$ & $\begin{array}{c}-0.015^{* * *} \\
(0.004)\end{array}$ & $\begin{array}{c}-0.011^{* * *} \\
(0.004)\end{array}$ & $\begin{array}{l}-0.009 \\
(0.006)\end{array}$ & $\begin{array}{c}0.089 * * * \\
(0.012)\end{array}$ & $\begin{array}{c}0.129 * * * \\
(0.018)\end{array}$ & $\begin{array}{c}-0.036^{* * *} \\
(0.008)\end{array}$ & $\begin{array}{c}-0.045^{* * *} \\
(0.013)\end{array}$ & $\begin{array}{l}-0.009 \\
(0.006)\end{array}$ & $\begin{array}{c}-0.033^{* * *} \\
(0.010)\end{array}$ \\
\hline The Netherlands $(N=7,155)$ & $\begin{array}{c}-0.031^{* * *} \\
(0.004)\end{array}$ & $\begin{array}{c}-0.063 * * * \\
(0.007)\end{array}$ & $\begin{array}{c}-0.040 * * * \\
(0.007)\end{array}$ & $\begin{array}{c}-0.072 * * * \\
(0.013)\end{array}$ & $\begin{array}{c}-0.103^{* * *} \\
(0.013)\end{array}$ & $\begin{array}{c}0.638 * * * \\
(0.032)\end{array}$ & $\begin{array}{c}-0.103^{* * *} \\
(0.013)\end{array}$ & $\begin{array}{c}-0.235^{* * *} \\
(0.024)\end{array}$ & $\begin{array}{c}-0.069 * * * \\
(0.010)\end{array}$ & $\begin{array}{c}-0.181^{* * *} \\
(0.019) \\
0\end{array}$ \\
\hline Spain $(N=13,198)$ & $\begin{array}{c}-0.024 * * * \\
(0.002)\end{array}$ & $\begin{array}{c}-0.037 * * * \\
(0.005)\end{array}$ & $\begin{array}{c}-0.013^{* * *} \\
(0.003)\end{array}$ & $\begin{array}{c}-0.028 * * * \\
(0.006)\end{array}$ & $\begin{array}{c}0.207 * * * \\
(0.011)\end{array}$ & $\begin{array}{c}0.365^{* * *} \\
(0.020)\end{array}$ & $\begin{array}{c}-0.055^{* * *} \\
(0.008)\end{array}$ & $\begin{array}{c}-0.094^{* * *} \\
(0.015)\end{array}$ & $\begin{array}{c}-0.059 * * * \\
(0.006)\end{array}$ & $\begin{array}{c}-0.110 * * * \\
(0.012)\end{array}$ \\
\hline The United Kingdom $(N=6,104)$ & $\begin{array}{c}-0.014 * * * \\
(0.003)\end{array}$ & $\begin{array}{c}-0.027 * * * \\
(0.007)\end{array}$ & $\begin{array}{c}-0.010 * * \\
(0.005)\end{array}$ & $\begin{array}{l}-0.010 \\
(0.011)\end{array}$ & $\begin{array}{c}0.252 * * * \\
(0.014)\end{array}$ & $\begin{array}{c}0.516^{* * *} \\
(0.031)\end{array}$ & $\begin{array}{c}-0.052^{* * *} \\
(0.010)\end{array}$ & $\begin{array}{c}-0.107^{* * *} \\
(0.022)\end{array}$ & $\begin{array}{c}-0.102 * * * \\
(0.008)\end{array}$ & $\begin{array}{c}-0.198 * * * \\
(0.017)\end{array}$ \\
\hline
\end{tabular}


Table 2-B. Estimates of the effect of health status on various time use categories using MTUS data, females

\begin{tabular}{|c|c|c|c|c|c|c|c|c|c|c|}
\hline \multirow[b]{3}{*}{ Females } & (1) & (2) & (3) & (4) & (5) & (6) & (7) & (8) & (9) & (10) \\
\hline & \multicolumn{2}{|c|}{ Sleep } & \multicolumn{2}{|c|}{ Personal Care } & \multicolumn{2}{|c|}{ Market work } & \multicolumn{2}{|c|}{ Non-Market work } & \multicolumn{2}{|c|}{ Leisure } \\
\hline & SAHS & $\begin{array}{c}\text { GOOD } \\
\text { HEALTH }\end{array}$ & SAHS & $\begin{array}{c}\text { GOOD } \\
\text { HEALTH }\end{array}$ & SAHS & $\begin{array}{c}\text { GOOD } \\
\text { HEALTH }\end{array}$ & SAHS & $\begin{array}{c}\text { GOOD } \\
\text { HEALTH }\end{array}$ & SAHS & $\begin{array}{c}\text { GOOD } \\
\text { HEALTH }\end{array}$ \\
\hline France $(N=4,977)$ & $\begin{array}{c}-0.026 * * * \\
(0.003)\end{array}$ & $\begin{array}{c}-0.040 * * * \\
(0.006)\end{array}$ & $\begin{array}{c}-0.022 * * * \\
(0.006)\end{array}$ & $\begin{array}{c}-0.037 * * * \\
(0.010)\end{array}$ & $\begin{array}{c}0.137 * * * \\
(0.018)\end{array}$ & $\begin{array}{c}0.238 * * * \\
(0.033)\end{array}$ & $\begin{array}{l}-0.019 * \\
(0.010)\end{array}$ & $\begin{array}{c}-0.038^{* *} \\
(0.018)\end{array}$ & $\begin{array}{l}-0.005 \\
(0.010)\end{array}$ & $\begin{array}{l}-0.012 \\
(0.018)\end{array}$ \\
\hline Germany $(N=11,381)$ & $\begin{array}{c}-0.013^{* * *} \\
(0.002)\end{array}$ & $\begin{array}{c}-0.017^{* * *} \\
(0.004)\end{array}$ & $\begin{array}{c}-0.022^{* * *} \\
(0.004)\end{array}$ & $\begin{array}{c}-0.034^{* * *} \\
(0.007)\end{array}$ & $\begin{array}{c}0.092 * * * \\
(0.012)\end{array}$ & $\begin{array}{c}0.100^{* * *} \\
(0.019)\end{array}$ & $\begin{array}{c}-0.027^{* * *} \\
(0.007)\end{array}$ & $\begin{array}{c}-0.028 * * \\
(0.011)\end{array}$ & $\begin{array}{c}0.001 \\
(0.006)\end{array}$ & $\begin{array}{c}0.007 \\
(0.010)\end{array}$ \\
\hline Italy $(N=14,371)$ & $\begin{array}{c}-0.010^{* * *} \\
(0.002)\end{array}$ & $\begin{array}{c}-0.008^{* *} \\
(0.003)\end{array}$ & $\begin{array}{c}0.012 * * * \\
(0.003)\end{array}$ & $\begin{array}{c}0.012 * * \\
(0.005)\end{array}$ & $\begin{array}{c}0.018 \\
(0.012)\end{array}$ & $\begin{array}{l}0.030 * \\
(0.017)\end{array}$ & $\begin{array}{c}-0.024^{* * *} \\
(0.007)\end{array}$ & $\begin{array}{c}-0.041^{* * *} \\
(0.010)\end{array}$ & $\begin{array}{c}0.023^{* * *} \\
(0.006)\end{array}$ & $\begin{array}{c}0.030 * * * \\
(0.009)\end{array}$ \\
\hline The Netherlands $(N=10,691)$ & $\begin{array}{c}-0.038^{* * *} \\
(0.003)\end{array}$ & $\begin{array}{c}-0.074 * * * \\
(0.005)\end{array}$ & $\begin{array}{c}-0.021^{* * *} \\
(0.005)\end{array}$ & $\begin{array}{c}-0.034^{* * *} \\
(0.009)\end{array}$ & $\begin{array}{c}0.167^{* * *} \\
(0.013)\end{array}$ & $\begin{array}{c}0.347 * * * \\
(0.024)\end{array}$ & $\begin{array}{c}-0.023^{* * *} \\
(0.008)\end{array}$ & $\begin{array}{c}-0.051^{* * *} \\
(0.015)\end{array}$ & $\begin{array}{l}-0.012 * \\
(0.007)\end{array}$ & $\begin{array}{l}-0.015 \\
(0.013)\end{array}$ \\
\hline Spain $(N=15,425)$ & $\begin{array}{c}-0.018^{* * *} \\
(0.002)\end{array}$ & $\begin{array}{c}-0.028^{* * *} \\
(0.004)\end{array}$ & $\begin{array}{l}-0.005^{*} \\
(0.003)\end{array}$ & $\begin{array}{c}-0.013^{* * *} \\
(0.005)\end{array}$ & $\begin{array}{c}0.083^{* * *} \\
(0.010)\end{array}$ & $\begin{array}{c}0.151^{* * * *} \\
(0.018)\end{array}$ & $\begin{array}{l}-0.010 * \\
(0.006)\end{array}$ & $\begin{array}{c}-0.025^{* *} \\
(0.011)\end{array}$ & $\begin{array}{l}-0.008 \\
(0.006)\end{array}$ & $\begin{array}{l}-0.018^{*} \\
(0.010)\end{array}$ \\
\hline The United Kingdom $(N=7,090)$ & $\begin{array}{c}-0.016^{* * *} \\
(0.003)\end{array}$ & $\begin{array}{c}-0.028 * * * \\
(0.006)\end{array}$ & $\begin{array}{c}-0.012^{* * *} \\
(0.005)\end{array}$ & $\begin{array}{c}-0.027 * * * \\
(0.010)\end{array}$ & $\begin{array}{c}0.167^{* * *} \\
(0.013)\end{array}$ & $\begin{array}{c}0.331^{* * *} \\
(0.027)\end{array}$ & $\begin{array}{c}-0.018 * * \\
(0.008)\end{array}$ & $\begin{array}{c}-0.053^{* * *} \\
(0.017)\end{array}$ & $\begin{array}{c}-0.039 * * * \\
(0.007)\end{array}$ & $\begin{array}{c}-0.079 * * * \\
(0.014)\end{array}$ \\
\hline $\begin{array}{l}\text { Notes: Robust standard errors in } \\
\text { in the Multinational Time Use } \\
\text { secondary and university educat } \\
\text { child is } 5-12 \text {, whether the young } \\
\text { use activities are measured in } 1 \\
* * * \text { Significant at the } 99 \% \text { level. }\end{array}$ & thesis. & $\overline{a m p}$ & 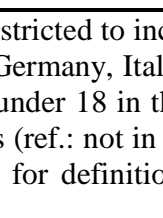 & te & 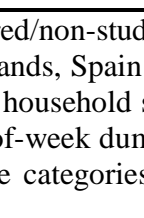 & ' & (3) & - & 65 (in & $\begin{array}{l}\text { e) included } \\
\text { its square, } \\
\text { e youngest } \\
\text { ber). Time }\end{array}$ \\
\hline
\end{tabular}


Table 3-A. Correlation matrix of residuals, males

\begin{tabular}{|c|c|c|c|c|c|c|}
\hline Males & & $\begin{array}{c}\text { (1) } \\
\text { Sleep } \\
\end{array}$ & $\begin{array}{c}(2) \\
\text { Personal } \\
\text { Care } \\
\end{array}$ & $\begin{array}{c}\text { (3) } \\
\text { Market work }\end{array}$ & $\begin{array}{c}\text { (4) } \\
\begin{array}{c}\text { Non-Market } \\
\text { work }\end{array} \\
\end{array}$ & $\begin{array}{r}(5) \\
\text { Leisure } \\
\end{array}$ \\
\hline France $(N=4,443)$ & Sleep & 1.00 & - & - & - & - \\
\hline Germany $(N=9,511)$ & & 1.00 & - & - & - & - \\
\hline Italy $(N=13,155)$ & & 1.00 & - & - & - & - \\
\hline The Netherlands $(N=7,155)$ & & 1.00 & - & - & - & - \\
\hline Spain $(N=13,198)$ & & 1.00 & - & - & - & - \\
\hline The United Kingdom $(N=6,104)$ & & 1.00 & - & - & - & - \\
\hline France $(N=4,443)$ & Personal care & 0.06 & 1.00 & - & - & - \\
\hline Germany $(N=9,511)$ & & 0.00 & 1.00 & - & - & - \\
\hline Italy $(N=13,155)$ & & 0.01 & 1.00 & - & - & - \\
\hline The Netherlands $(N=7,155)$ & & -0.01 & 1.00 & - & - & - \\
\hline Spain $(N=13,198)$ & & 0.00 & 1.00 & - & - & - \\
\hline The United Kingdom $(N=6,104)$ & & -0.02 & 1.00 & - & - & - \\
\hline France $(N=4,443)$ & Market work & -0.38 & -0.25 & 1.00 & - & - \\
\hline Germany $(N=9,511)$ & & -0.35 & -0.31 & 1.00 & - & - \\
\hline Italy $(N=13,155)$ & & -0.37 & -0.31 & 1.00 & - & - \\
\hline The Netherlands $(N=7,155)$ & & -0.36 & -0.22 & 1.00 & - & - \\
\hline Spain $(N=13,198)$ & & -0.38 & -0.26 & 1.00 & - & - \\
\hline The United Kingdom $(N=6,104)$ & & -0.34 & -0.11 & 1.00 & - & - \\
\hline France $(N=4,443)$ & Non-market work & 0.06 & 0.15 & -0.07 & 1.00 & - \\
\hline Germany $(N=9,511)$ & & 0.05 & 0.10 & -0.49 & 1.00 & - \\
\hline Italy $(N=13,155)$ & & 0.02 & 0.09 & -0.43 & 1.00 & - \\
\hline The Netherlands $(N=7,155)$ & & 0.10 & 0.12 & -0.50 & 1.00 & - \\
\hline Spain $(N=13,198)$ & & 0.02 & 0.05 & -0.44 & 1.00 & - \\
\hline The United Kingdom $(N=6,104)$ & & 0.05 & 0.11 & -0.50 & 1.00 & - \\
\hline France $(N=4,443)$ & Leisure & -0.04 & -0.07 & -0.63 & 0.07 & 1.00 \\
\hline Germany $(N=9,511)$ & & -0.07 & 0.00 & -0.49 & -0.08 & 1.00 \\
\hline Italy $(N=13,155)$ & & -0.05 & 0.05 & -0.59 & 0.00 & 1.00 \\
\hline The Netherlands $(N=7,155)$ & & -0.07 & -0.10 & -0.50 & -0.05 & 1.00 \\
\hline Spain $(N=13,198)$ & & 0.05 & 0.05 & -0.63 & 0.03 & 1.00 \\
\hline The United Kingdom $(N=6,104)$ & & -0.03 & -0.08 & -0.60 & 0.01 & 1.00 \\
\hline
\end{tabular}

Notes: Robust standard errors in parenthesis. The sample is restricted to include non-retired/non-student individuals between the ages of 21 and 65 (inclusive) included in the Multinational Time Use Study (MTUS) from France, Germany, Italy, the Netherlands, Spain and the United Kingdom. Regressions include age and its square, secondary and university education, the number of children under 18 in the household, household size, whether the youngest child is under 5, whether the youngest child is 5-12, whether the youngest child is 13-17, civil status (ref.: not in couple), day-of-week dummies (ref.: Saturday) and month dummies (ref.: December). Time use activities are measured in hours per day,

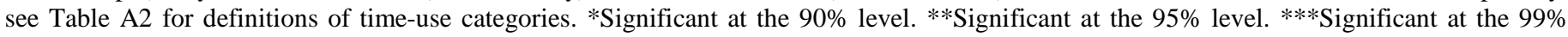
level. 
Table 3-B. Correlation matrix of residuals, females

\begin{tabular}{|c|c|c|c|c|c|c|}
\hline Females & & $\begin{array}{c}\text { (1) } \\
\text { Sleep } \\
\end{array}$ & $\begin{array}{c}(2) \\
\text { Personal } \\
\text { Care } \\
\end{array}$ & $\begin{array}{c}\text { (3) } \\
\text { Market work } \\
\end{array}$ & $\begin{array}{c}\text { (4) } \\
\begin{array}{c}\text { Non-Market } \\
\text { work }\end{array} \\
\end{array}$ & $\begin{array}{c}\text { (5) } \\
\text { Leisure }\end{array}$ \\
\hline France $(N=4,977)$ & Sleep & 1.00 & - & - & - & - \\
\hline Germany $(N=11,381)$ & & 1.00 & - & - & - & - \\
\hline Italy $(N=14,371)$ & & 1.00 & - & - & - & - \\
\hline The Netherlands $(N=10,691)$ & & 1.00 & - & - & - & - \\
\hline Spain $(N=15,425)$ & & 1.00 & - & - & - & - \\
\hline The United Kingdom $(N=7,090)$ & & 1.00 & - & - & - & - \\
\hline France $(N=4,977)$ & Personal care & 0.00 & 1.00 & - & - & - \\
\hline Germany $(N=11,381)$ & & -0.03 & 1.00 & - & - & - \\
\hline Italy $(N=14,371)$ & & -0.06 & 1.00 & - & - & - \\
\hline The Netherlands $(N=10,691)$ & & -0.05 & 1.00 & - & - & - \\
\hline Spain $(N=15,425)$ & & -0.04 & 1.00 & - & - & - \\
\hline The United Kingdom $(N=7,090)$ & & -0.08 & 1.00 & - & - & - \\
\hline France $(N=4,977)$ & Market work & -0.29 & -0.29 & 1.00 & - & - \\
\hline Germany $(N=11,381)$ & & -0.27 & -0.30 & 1.00 & - & - \\
\hline Italy $(N=14,371)$ & & -0.22 & -0.29 & 1.00 & - & - \\
\hline The Netherlands $(N=10,691)$ & & -0.29 & -0.21 & 1.00 & - & - \\
\hline Spain $(N=15,425)$ & & -0.27 & -0.24 & 1.00 & - & - \\
\hline The United Kingdom $(N=7,090)$ & & -0.25 & -0.12 & 1.00 & - & - \\
\hline France $(N=4,977)$ & Non-market work & 0.05 & 0.23 & -0.62 & 1.00 & - \\
\hline Germany $(N=11,381)$ & & -0.01 & 0.02 & -0.47 & 1.00 & - \\
\hline Italy $(N=14,371)$ & & -0.01 & 0.04 & -0.58 & 1.00 & - \\
\hline The Netherlands $(N=10,691)$ & & -0.02 & 0.12 & -0.50 & 1.00 & - \\
\hline Spain $(N=15,425)$ & & -0.08 & 0.02 & -0.52 & 1.00 & - \\
\hline The United Kingdom $(N=7,090)$ & & -0.01 & 0.08 & -0.53 & 1.00 & - \\
\hline France $(N=4,977)$ & Leisure & -0.09 & -0.10 & -0.55 & 0.04 & 1.00 \\
\hline Germany $(N=11,381)$ & & -0.11 & -0.02 & -0.44 & -0.18 & 1.00 \\
\hline Italy $(N=14,371)$ & & -0.12 & 0.06 & -0.46 & -0.09 & 1.00 \\
\hline The Netherlands $(N=10,691)$ & & -0.09 & -0.11 & -0.46 & -0.12 & 1.00 \\
\hline Spain $(N=15,425)$ & & -0.03 & 0.05 & -0.53 & -0.05 & 1.00 \\
\hline The United Kingdom $(N=7,090)$ & & -0.10 & -0.13 & -0.52 & -0.08 & 1.00 \\
\hline
\end{tabular}




\section{APPENDIX}

Table A1. Description of time use surveys

\begin{tabular}{lclcc}
\hline \hline Country & Year & Survey coverage & $\begin{array}{c}\text { Original } \\
\text { sample size }\end{array}$ & $\begin{array}{c}\text { Analysis } \\
\text { sample size }\end{array}$ \\
\hline France & 1998 & 16 February 1998 - 14 February 1999 & 15,441 diaries & 9,420 diaries \\
Germany & 2001 & April 2001 - March 2002 & 35,813 diaries & 20,892 diaries \\
Italy & 2002 & April 2002 - March 2003 & 51,206 diaries & 27,526 diaries \\
The Netherlands & 2000 & Oct-00 & 15,428 diaries & 8,454 diaries \\
& 2005 & Oct-05 & 12,691 diaries & 9,392 diaries \\
Spain & 2002 & October 2002- October 2003 & 46,774 diaries & 28.623 diaries \\
The United Kingdom & 2000 & June 2000 - August 2001 & 19,400 diaries & 11,127 diaries \\
& 2005 & & 4,941 diaries & 2,067 diaries
\end{tabular}

Source: Multinational Time Use Study (MTUS, www.timeuse.org) version 553 and harmonized surveys by authors. "Analysis sample size" refers to the number of observations from each survey that we use in our main empirical analysis. We restrict the sample to include only those individuals who had time diaries that summed to a complete day (i.e., 1440 minutes). All surveys include sample weights, and weights are adjusted to ensure each day of the week and each survey are uniformly represented. 
Table A2. Classification of time use activities

\begin{tabular}{|c|c|}
\hline Time use categories & Time use activity codes \\
\hline Sleep & "Sleep" \\
\hline Personal Care & "Dress/personal care", "Consume personal services", "Meals and snacks" \\
\hline Market work & $\begin{array}{l}\text { "Paid work", "Paid work at home", "Paid work, second job", "Travel to/from } \\
\text { work", "School, classes", "Study, homework” }\end{array}$ \\
\hline Non-Market work & $\begin{array}{l}\text { "Cook, wash up", "Housework", "Odd jobs", "Gardening", "Shopping", } \\
\text { "Childcare", "Domestic travel" }\end{array}$ \\
\hline Housework & "Cook, wash up", "Housework" \\
\hline Childcare & "Childcare" \\
\hline Shopping & "Shopping" \\
\hline Other housework & "Gardening", "Shopping", "Domestic travel" \\
\hline TV watching & $\begin{array}{l}\text { "Free time travel", "Excursions", "Active sports participation", "Passive sports } \\
\text { participation", "Walking", "Cinema or theatre", "Dances or parties", "Social } \\
\text { clubs", "Pubs", "Restaurants", "Visit friends at their homes", "Listen to radio", } \\
\text { "Watch television or video", "Listen to records, tapes, cds", "Read books", "Read } \\
\text { papers, magazines", "Relax", "Conversation", "Entertain friends at home", "Knit, } \\
\text { sew", "Other leisure", "Religious activities", "Civic activities" } \\
\text { Watch television or video }\end{array}$ \\
\hline Out of home leisure & $\begin{array}{l}\text { "Free time travel", "Excursions", "Active sports participation", "Walking", } \\
\text { "Cinema or theatre", "Dances or parties", "Social clubs", "Pubs", "Restaurants", } \\
\text { "Visit friends at their homes". }\end{array}$ \\
\hline Reading/listening & $\begin{array}{l}\text { "Listen to radio", "Listen to records, tapes, cds,", "Read books", "Read papers, } \\
\text { magazines" }\end{array}$ \\
\hline Other leisure & $\begin{array}{l}\text { "Passive sports participation", "Relax", "Conversation", "Entertain friends at } \\
\text { home", "Knit, sew", "Other leisure" }\end{array}$ \\
\hline Civic/religious & "Religious activities", "Civic activities" \\
\hline
\end{tabular}

Source: Multinational Time Use Study (MTUS). 
Table A3. Sum stats of demographic characteristics of the samples

\begin{tabular}{|c|c|c|c|c|c|c|c|c|c|c|c|c|}
\hline & \multicolumn{2}{|c|}{ France } & \multicolumn{2}{|c|}{ Germany } & \multicolumn{2}{|c|}{ Italy } & \multicolumn{2}{|c|}{ The Netherlands } & \multicolumn{2}{|c|}{ Spain } & \multicolumn{2}{|c|}{ The United Kingdom } \\
\hline & $\underline{\text { Mean }}$ & $\underline{\mathrm{SE}}$ & $\underline{\text { Mean }}$ & $\underline{\mathrm{SE}}$ & Mean & $\underline{\mathrm{SE}}$ & Mean & $\underline{\mathrm{SE}}$ & $\underline{\text { Mean }}$ & $\underline{\mathrm{SE}}$ & Mean & $\underline{\mathrm{SE}}$ \\
\hline \multicolumn{13}{|l|}{ Panel A: Males } \\
\hline Age & 40.426 & $(10.057)$ & 43.741 & $(10.095)$ & 40.230 & $(10.694)$ & 42.259 & $(10.360)$ & 41.668 & (11.266) & 41.482 & $(11.377)$ \\
\hline Secondary education & 0.497 & $(0.500)$ & 0.474 & $(0.499)$ & 0.788 & $(0.408)$ & 0.351 & $(0.477)$ & 0.540 & $(0.498)$ & 0.395 & $(0.489)$ \\
\hline University education & 0.352 & $(0.478)$ & 0.455 & $(0.498)$ & 0.107 & $(0.309)$ & 0.445 & $(0.497)$ & 0.260 & $(0.438)$ & 0.289 & $(0.453)$ \\
\hline number of children $<18$ & 0.923 & (1.119) & 0.807 & $(0.900)$ & 0.643 & $(0.914)$ & 0.805 & $(1.087)$ & 0.710 & $(0.920)$ & 0.801 & (1.086) \\
\hline Household size & 3.204 & $(1.391)$ & 3.270 & $(1.269)$ & 3.367 & $(1.195)$ & 2.829 & $(1.380)$ & 3.594 & $(1.297)$ & 2.962 & $(1.365)$ \\
\hline Age youngest child <4 & 0.182 & $(0.386)$ & 0.138 & $(0.345)$ & 0.074 & $(0.261)$ & 0.173 & $(0.378)$ & 0.155 & $(0.362)$ & 0.165 & $(0.371)$ \\
\hline Age youngest child 5-11 & 0.212 & $(0.409)$ & 0.255 & $(0.436)$ & 0.211 & $(0.408)$ & 0.172 & $(0.377)$ & 0.172 & $(0.377)$ & 0.175 & $(0.380)$ \\
\hline Age youngest child 13-17 & 0.114 & $(0.318)$ & 0.146 & $(0.353)$ & 0.105 & $(0.306)$ & 0.074 & $(0.261)$ & 0.121 & $(0.327)$ & 0.093 & $(0.291)$ \\
\hline Living in couple & 0.771 & $(0.420)$ & 0.807 & $(0.394)$ & 0.656 & $(0.475)$ & 0.766 & $(0.423)$ & 0.705 & $(0.456)$ & 0.759 & $(0.427)$ \\
\hline \multicolumn{13}{|l|}{ Panel B: Females } \\
\hline Age & 40.842 & $(10.726)$ & 42.869 & $(9.498)$ & 41.226 & (11.068) & 42.323 & $(11.236)$ & 42.537 & (11.557) & 39.822 & $(10.807)$ \\
\hline Secondary education & 0.466 & $(0.499)$ & 0.612 & $(0.487)$ & 0.728 & $(0.445)$ & 0.461 & $(0.498)$ & 0.511 & $(0.500)$ & 0.391 & $(0.488)$ \\
\hline University education & 0.368 & $(0.482)$ & 0.268 & $(0.443)$ & 0.101 & $(0.302)$ & 0.339 & $(0.474)$ & 0.239 & $(0.427)$ & 0.285 & $(0.452)$ \\
\hline number of children $<18$ & 0.929 & $(1.125)$ & 0.827 & $(0.890)$ & 0.641 & $(0.910)$ & 0.794 & $(1.051)$ & 0.707 & $(0.923)$ & 0.957 & $(1.135)$ \\
\hline Household size & 3.153 & $(1.372)$ & 3.119 & $(1.233)$ & 3.341 & $(1.163)$ & 2.807 & $(1.277)$ & 3.545 & $(1.318)$ & 3.051 & $(1.333)$ \\
\hline Age youngest child <4 & 0.178 & $(0.383)$ & 0.128 & $(0.334)$ & 0.071 & $(0.257)$ & 0.177 & $(0.382)$ & 0.150 & $(0.357)$ & 0.190 & $(0.392)$ \\
\hline Age youngest child 5-11 & 0.218 & $(0.413)$ & 0.270 & $(0.444)$ & 0.210 & $(0.408)$ & 0.174 & $(0.379)$ & 0.175 & $(0.380)$ & 0.218 & $(0.413)$ \\
\hline Age youngest child 13-17 & 0.117 & $(0.321)$ & 0.163 & $(0.369)$ & 0.110 & $(0.313)$ & 0.076 & $(0.264)$ & 0.122 & $(0.327)$ & 0.106 & $(0.307)$ \\
\hline Living in couple & 0.773 & $(0.419)$ & 0.733 & $(0.442)$ & 0.722 & $(0.448)$ & 0.769 & $(0.421)$ & 0.724 & $(0.447)$ & 0.708 & $(0.455)$ \\
\hline
\end{tabular}

Study (MTUS) from France, Germany, Italy, the Netherlands, Spain and the United Kingdom. 
Table A4. Estimates of the effect of health status on components of non-market work and leisure using MTUS data, males

\begin{tabular}{|c|c|c|c|c|c|c|c|c|c|}
\hline \multirow[b]{3}{*}{ Males } & (1) & (2) & (3) & (4) & (5) & (6) & (7) & (8) & (9) \\
\hline & \multicolumn{4}{|c|}{ Non-Market work } & \multicolumn{5}{|c|}{ Leisure } \\
\hline & Housework & Childcare & Shopping & $\begin{array}{c}\text { Other } \\
\text { housework }\end{array}$ & TV watching & $\begin{array}{c}\text { Out of home } \\
\text { leisure }\end{array}$ & $\begin{array}{l}\text { Reading } \\
\text { listening }\end{array}$ & Other leisure & $\begin{array}{c}\text { Civic } \\
\text { Voluntary }\end{array}$ \\
\hline France $(N=4,443)$ & $\begin{array}{l}-0.011 \\
(0.009)\end{array}$ & $\begin{array}{l}-0.001 \\
(0.006)\end{array}$ & $\begin{array}{l}-0.013 \\
(0.008)\end{array}$ & $\begin{array}{l}-0.016^{*} \\
(0.010)\end{array}$ & $\begin{array}{c}-0.080 * * * \\
(0.012)\end{array}$ & $\begin{array}{l}-0.005 \\
(0.014)\end{array}$ & $\begin{array}{l}-0.007 \\
(0.007)\end{array}$ & $\begin{array}{c}0.004 \\
(0.013)\end{array}$ & $\begin{array}{c}0.019 * * * \\
(0.006)\end{array}$ \\
\hline Germany $(N=9,511)$ & $\begin{array}{l}-0.003 \\
(0.007)\end{array}$ & $\begin{array}{l}-0.008^{*} \\
(0.005)\end{array}$ & $\begin{array}{l}-0.005 \\
(0.005)\end{array}$ & $\begin{array}{c}-0.017^{* *} \\
(0.008)\end{array}$ & $\begin{array}{c}-0.070 * * * \\
(0.009)\end{array}$ & $\begin{array}{c}0.037 * * * \\
(0.010)\end{array}$ & $\begin{array}{c}0.001 \\
(0.006)\end{array}$ & $\begin{array}{c}-0.021 * * * \\
(0.008)\end{array}$ & $\begin{array}{c}0.009 \\
(0.007)\end{array}$ \\
\hline Italy $(N=13,155)$ & $\begin{array}{c}-0.016 * * * \\
(0.005)\end{array}$ & $\begin{array}{c}0.000 \\
(0.004)\end{array}$ & $\begin{array}{c}0.000 \\
(0.004)\end{array}$ & $\begin{array}{c}-0.017^{* * *} \\
(0.006)\end{array}$ & $\begin{array}{c}-0.047 * * * \\
(0.007)\end{array}$ & $\begin{array}{c}0.045^{* * *} \\
(0.008)\end{array}$ & $\begin{array}{l}-0.007^{*} \\
(0.005)\end{array}$ & $\begin{array}{c}-0.020 * * * \\
(0.007)\end{array}$ & $\begin{array}{c}0.001 \\
(0.003)\end{array}$ \\
\hline The Netherlands $(N=7,155)$ & $\begin{array}{c}-0.056^{* * *} \\
(0.009)\end{array}$ & $\begin{array}{l}-0.011^{*} \\
(0.006)\end{array}$ & $\begin{array}{c}-0.029 * * * \\
(0.007)\end{array}$ & $\begin{array}{c}-0.064^{* * *} \\
(0.010)\end{array}$ & $\begin{array}{c}-0.057^{* * *} \\
(0.012)\end{array}$ & $\begin{array}{c}0.014 \\
(0.014)\end{array}$ & $\begin{array}{c}-0.021^{* *} \\
(0.010)\end{array}$ & $\begin{array}{c}-0.067 * * * \\
(0.012)\end{array}$ & $\begin{array}{l}-0.005 \\
(0.006)\end{array}$ \\
\hline Spain $(N=13,198)$ & $\begin{array}{c}-0.025^{* * *} \\
(0.005)\end{array}$ & $\begin{array}{l}-0.002 \\
(0.003)\end{array}$ & $\begin{array}{c}-0.016^{* * * *} \\
(0.004)\end{array}$ & $\begin{array}{c}-0.038^{* * *} \\
(0.006)\end{array}$ & $\begin{array}{c}-0.057 * * * \\
(0.006)\end{array}$ & $\begin{array}{c}-0.017^{* *} \\
(0.008)\end{array}$ & $\begin{array}{c}-0.019 * * * \\
(0.004)\end{array}$ & $\begin{array}{c}-0.033^{* * *} \\
(0.007)\end{array}$ & $\begin{array}{c}-0.006^{* *} \\
(0.003)\end{array}$ \\
\hline The United Kingdom $(N=6,104)$ & $\begin{array}{c}-0.026^{* * *} \\
(0.007)\end{array}$ & $\begin{array}{l}-0.006 \\
(0.005)\end{array}$ & $\begin{array}{c}-0.025^{* * *} \\
(0.006)\end{array}$ & $\begin{array}{c}-0.031^{* * *} \\
(0.008)\end{array}$ & $\begin{array}{c}-0.100 * * * \\
(0.010)\end{array}$ & $\begin{array}{l}-0.021^{*} \\
(0.011)\end{array}$ & $\begin{array}{l}-0.008 \\
(0.006)\end{array}$ & $\begin{array}{c}-0.058^{* * *} \\
(0.009)\end{array}$ & $\begin{array}{c}-0.009 * * * \\
(0.004)\end{array}$ \\
\hline
\end{tabular}

Notes: Robust standard errors in parenthesis. The sample is restricted to include non-retired/non-student individuals between the ages of 21 and 65 (inclusive) included in the Multinational Time Use Study (MTUS) from France, Germany, Italy, the Netherlands, Spain and the United Kingdom. Regressions include age and its square, secondary and university education, the number of children under 18 in the household, household size, whether the youngest child is under 5, whether the youngest child is 5-12, whether the youngest child is 1317, civil status (ref.: not in couple), day-of-week dummies (ref.: Saturday) and month dummies (ref.: December). Time use activities are measured in hours per day, see Table A2 for definitions of time-use categories. *Significant at the $90 \%$ level. **Significant at the $95 \%$ level. ***Significant at the $99 \%$ level. 
Table A5. Estimates of the effect of health status on components of non-market work and leisure using MTUS data, males

\begin{tabular}{|c|c|c|c|c|c|c|c|c|c|}
\hline \multirow[b]{3}{*}{ Females } & (1) & (2) & (3) & (4) & (5) & (6) & (7) & (8) & (9) \\
\hline & \multicolumn{4}{|c|}{ Non-Market work } & \multicolumn{5}{|c|}{ Leisure } \\
\hline & Housework & Childcare & Shopping & $\begin{array}{c}\begin{array}{c}\text { Other } \\
\text { housework }\end{array} \\
\end{array}$ & TV watching & $\begin{array}{c}\begin{array}{c}\text { Out of home } \\
\text { leisure }\end{array} \\
\end{array}$ & $\begin{array}{l}\text { Reading } \\
\text { listening }\end{array}$ & Other leisure & $\begin{array}{c}\text { Civic } \\
\text { Voluntary } \\
\end{array}$ \\
\hline France $(N=4,977)$ & $\begin{array}{c}-0.029 * * * \\
(0.010)\end{array}$ & $\begin{array}{c}0.001 \\
(0.007)\end{array}$ & $\begin{array}{c}0.001 \\
(0.009)\end{array}$ & $\begin{array}{c}0.016 \\
(0.010)\end{array}$ & $\begin{array}{c}-0.062 * * * \\
(0.011)\end{array}$ & $\begin{array}{c}0.040 * * * \\
(0.013)\end{array}$ & $\begin{array}{c}0.007 \\
(0.007)\end{array}$ & $\begin{array}{c}0.004 \\
(0.010)\end{array}$ & $\begin{array}{l}-0.006 \\
(0.005)\end{array}$ \\
\hline Germany $(N=11,381)$ & $\begin{array}{l}-0.011 \\
(0.007)\end{array}$ & $\begin{array}{l}-0.002 \\
(0.005)\end{array}$ & $\begin{array}{l}-0.002 \\
(0.005)\end{array}$ & $\begin{array}{c}-0.014 * * \\
(0.007)\end{array}$ & $\begin{array}{c}-0.056^{* * *} \\
(0.008)\end{array}$ & $\begin{array}{c}0.049 * * * \\
(0.009)\end{array}$ & $\begin{array}{c}0.015^{* * *} \\
(0.005)\end{array}$ & $\begin{array}{c}-0.016^{* *} \\
(0.007)\end{array}$ & $\begin{array}{c}0.019 * * * \\
(0.006)\end{array}$ \\
\hline Italy $(N=14,371)$ & $\begin{array}{c}-0.026^{* * *} \\
(0.007)\end{array}$ & $\begin{array}{l}-0.002 \\
(0.005)\end{array}$ & $\begin{array}{c}0.018^{* * *} \\
(0.005)\end{array}$ & $\begin{array}{c}0.008 \\
(0.006)\end{array}$ & $\begin{array}{c}-0.022 * * * \\
(0.007)\end{array}$ & $\begin{array}{c}0.058 * * * \\
(0.008)\end{array}$ & $\begin{array}{l}0.008 * \\
(0.004)\end{array}$ & $\begin{array}{l}-0.002 \\
(0.007)\end{array}$ & $\begin{array}{l}-0.002 \\
(0.003)\end{array}$ \\
\hline The Netherlands $(N=10,691)$ & $\begin{array}{l}-0.010 \\
(0.007)\end{array}$ & $\begin{array}{l}-0.001 \\
(0.006)\end{array}$ & $\begin{array}{l}-0.005 \\
(0.006)\end{array}$ & $\begin{array}{l}-0.008 \\
(0.008)\end{array}$ & $\begin{array}{c}-0.053^{* * *} \\
(0.009)\end{array}$ & $\begin{array}{c}0.048^{* * *} \\
(0.011)\end{array}$ & $\begin{array}{l}0.012 * \\
(0.007)\end{array}$ & $\begin{array}{c}-0.041^{* * *} \\
(0.009)\end{array}$ & $\begin{array}{c}0.000 \\
(0.005)\end{array}$ \\
\hline Spain $(N=15,425)$ & $\begin{array}{c}-0.013^{* *} \\
(0.006)\end{array}$ & $\begin{array}{c}0.004 \\
(0.003)\end{array}$ & $\begin{array}{c}0.012 * * * \\
(0.004)\end{array}$ & $\begin{array}{c}0.007 \\
(0.005)\end{array}$ & $\begin{array}{c}-0.026 * * * \\
(0.006)\end{array}$ & $\begin{array}{c}0.034^{* * *} \\
(0.007)\end{array}$ & $\begin{array}{c}0.007 * * \\
(0.003)\end{array}$ & $\begin{array}{c}-0.019 * * * \\
(0.006)\end{array}$ & $\begin{array}{l}-0.003 \\
(0.002)\end{array}$ \\
\hline The United Kingdom $(N=7,090)$ & $\begin{array}{l}-0.009 \\
(0.007)\end{array}$ & $\begin{array}{l}-0.006 \\
(0.005)\end{array}$ & $\begin{array}{l}-0.002 \\
(0.006)\end{array}$ & $\begin{array}{c}0.001 \\
(0.008)\end{array}$ & $\begin{array}{c}-0.056^{* * *} \\
(0.008)\end{array}$ & $\begin{array}{c}0.027 * * * \\
(0.010)\end{array}$ & $\begin{array}{c}-0.012^{* *} \\
(0.005)\end{array}$ & $\begin{array}{c}-0.047^{* * *} \\
(0.008)\end{array}$ & $\begin{array}{c}0.001 \\
(0.004)\end{array}$ \\
\hline
\end{tabular}

Notes: Robust standard errors in parenthesis. The sample is restricted to include non-retired/non-student individuals between the ages of 21 and 65 (inclusive) included in the Multinational Time Use Study (MTUS) from France, Germany, Italy, the Netherlands, Spain and the United Kingdom. Regressions include age and its square, secondary and university education, the number of children under 18 in the household, household size, whether the youngest child is under 5, whether the youngest child is 5-12, whether the youngest child is 13-17, civil status (ref.: not in couple), day-of-week dummies (ref.: Saturday) and month dummies (ref.: December). Time use activities are measured in hours per day, see Table A2 for definitions of time-use categories. *Significant at the $90 \%$ level. **Significant at the $95 \%$ level. ***Significant at the $99 \%$ level. 